\title{
Diğer Alacaklar Hesap Grubunun Türkiye Finansal Raporlama Standartlarına (TFRS 1) Göre Açılış Finansal Tablolarına Aktarılması
}

\author{
Murat Erdoğana, Ayhan Benek ${ }^{\mathrm{b}^{*}}$ \\ aKastamonu Üniversitesi, İktisadi ve İdari Bilimler Fakültesi, Kastamonu \\ ${ }^{b}$ Kastamonu Üniversitesi, Sosyal Bilimler Enstitüsü, İşletme Bölümü. Kastamonu
}

\section{Öz}

Tek Düzen Hesap Planı muhasebe sistemi içerisinde Diğer Alacaklar hesap grubu; işletmenin esas faaliyet dışında kalan ve kısa vadede (en çok bir yıl içinde) tahsil edilmesi planlanan senetli, senetsiz alacak ile bu gruba ait şüpheli alacak ve şüpheli alacak karşıllğının izlenmesi ile ifade edilmektedir. Bu çalışmanın amacl; Türkiye Muhasebe Standartları rehberliğinde, TDHP'de yer alan Diğer Alacaklar grubundaki hesaplarn Türkiye Finansal Raporlama Standartlarına çeorilmesini incelemek ve araştırmaktır. Bu süreçte, Diğer Alacaklar hesap grubunun Türk Vergi Usul Kanunu'ndan TFRS'ye ilk geçiş aşamasında ne tür farkllıkların ortaya çıktığını ve Tek Düzen Hesap Planındaki Diğer Alacaklar grubundaki hesapların TFRS'de hangi hesaplarla bağlantı kurulduğu MOMTOS-DR yazılımı kullanılarak açıklanmaya çalışılmıştır. Yapılan çalışma neticesinde, işletme dışındaki kullanıcılara şeffaf, karşılaştırılabilir, doğrulanabilir, anlaşılabilir finansal tablolarla gerçeğe uygun bir şekilde sunum yapılarak ihtiyaca uygun faydal finansal bilgi sunulmuştur.

Anahtar Kelimeler: Türkiye Finansal Raporlama Standartlarn (TFRS), Türkiye Muhasebe Standartları (TMS), Diğer Alacaklar, MOMTOS-DR

\section{Transferring of Other Account Receivables Group to the Opening Financial Tables According to the Turkish Financial Reporting Standards (TFRS 1)}

\begin{abstract}
Other Accounts within the Uniform Accounting Plan accounting system is monitoring the account receivables, suspicious receivables and doubtful receivables that are excluded from the main activity of the enterprise and planned to be collected in short term (at most within one year),. The purpose of this study is to examine the conversion of the accounts in the Other Receivables group in TPL into Turkish Financial Reporting Standards. In this process, it was attempted to explain what kind of differences occurred in the first transition stage of TFRS from the Turkish Tax Procedural Law of the Other Accounts Receivable Group and which accounts were linked to the accounts in the Other Receivables in the Uniform Chart of Accounts in TFRS using MOMTOS-DR software. The study presents transparent, comparable, verifiable, and comprehensible financial information for external users.
\end{abstract}

Keywords: Turkish Financial Reporting Standards (TFRS), Turkish Accounting Standards (TMS), Other Receivables, MOMTOS-DR

\section{GíRiş}

Finansal tablolar, dünya genelinde birçok işletme tarafından, işletme dışındaki kullanıcılar için hazırlanmakta ve sunulmaktadır (Resmi Gazete, 2011). Türkiye Finansal Raporlama Standartların (TFRS) ilk kez uygulandığ finansal tablolar; ilk kez TFRS'lere uygun olarak düzenlenen ve TFRS'lerle uyumlu olduğunun üzerlerinde açık ve koşulsuz olarak belirtildiği yıllık finansal tablolardır (TFRS1-Md.3, 2017). İşletmeler, TFRS'lere geçişle birlikte, daha önce raporlanan finansal durumun, finansal 
performansın ve nakit akışının nasıl etkilendiğini gösterir (TFRS1-Md.23, 2017). İşletmelerin sahip olduğu faydalı finansal bilgilerin karşılaştırılabilir, doğrulanabilir, anlaşılabilirliği ile zamanında sunulması her geçen gün önemi artmaktadır. İşletmelerin finansal durumunu ve finansal tablolarla sunulan faydalı finansal bilginin işletme dışındaki kullanıcılara faydalı olabilmesi için ihtiyaca uygun olup ve açıklamayı amaçladığı hususu gerçeğe uygun bir şekilde sunmasıdır. Bu çalışmada amaç, Türkiye Muhasebe Standartları rehberliğinde, Tek Düzen Hesap Planında (TDHP) yer alan Diğer Alacaklar grubundaki hesapların Türkiye Finansal Raporlama Standartlarına çevrilmesini inceleyerek ortaya çıkan finansal tabloların TDHP ve TFRS arasındaki ilişkileri ile farklılıkları göstermek ve faydalı finansal bilgiyi işletme dışındaki kullanıcılara şeffaf bir şekilde sunmaktır.

Veri olarak TDHP 13* Diğer Alacaklar hesap grubuna göre oluşturulan senaryo ve buna bağlı olarak Yevmiye Kayıtları, Geçici ve Kesin Mizan, Gelir Tablosu ile Bilanço kullanılarak www.mumeyek.org adresinde bulunan MOMTOS-DR yazılımı yöntemi ile çeviri sonucunda Finansal Durum Tablosu, Nakit Akış Tablosu, Özkaynaklar Değişim Tablosu, Kar veya Zarar ve Diğer Kapsamlı Gelir Tabloları gibi şeffaf, karşılaştırılabilir, doğrulanabilir, anlaşılabilir, gerçeğe uygun bulgulara ulaşılmaya çalışılmıştır. TDHP $13^{*}$ Diğer Alacaklar hesap grubunda bulunan hesap kalemlerinin Türkiye Finansal Raporlama Standartlarının İlk Uygulamasına İlişkin Türkiye Finansal Raporlama Standardı (TFRS 1) çerçevesinde TDHP 13* Diğer Alacaklar hesap grubunun TFRS'lerin ilk kez uygulandığı Açılış Finansal Tablolarına aktarılması örnek olaylar ile incelenecektir. Süreç,

- TDHP $13^{*}$ Diğer Alacaklar hesap grubu

- TFRS $A C^{*}$ Finans Sektörü Faaliyetlerinden Alacaklar hesap grubu

- TFRS AE* İlişkili Taraflardan Ticari Alacaklar hesap grubu

- TFRS $A F^{*}$ Diğger Alacaklar hesap grubu

- TDHP 13* Diğer Alacaklar hesap grubunun TFRS'lerin ilk kez uygulandığ Açılış Finansal Tablolarına aktarılması şeklinde izlenecektir.

\section{Literatür İncelemesi}

\subsection{TDHP 13* Diğer Alacaklar Hesap Grubu}

Tekdüzen Hesap Çerçevesi, 13* Diğer Alacaklar hesap grubunu, 1** Dönen Varlıklar hesap sınıfında göstermiş; Hesap Planı, 131 Ortaklardan Alacaklar, 132 İştiraklerden Alacaklar, 133 Bağlı Ortaklıklardan Alacaklar, 135 Personelden Alacaklar, 136 Diğer Çeşitli Alacaklar, 137 Diğer Alacak Senetleri Reeskontu (-), 138 Şüpheli Diğer Alacaklar,139 Şüpheli Diğer Alacaklar Karşılığı hesaplarını da 13* Diğer Alacaklar hesap grubunda vermiştir. Hesap Planı Açılamaları, 13* Diğer Alacaklar hesap grubunu, "bu hesap grubu; herhangi bir ticari nedene dayanmadan meydana gelmiş ve en çok bir yıl içinde tahsil edilmesi düşünülen senetli, senetsiz alacaklar ile bu gruba ait şüpheli alacak ve şüpheli alacak karşılığının izlenmesini sağlar (Resmi Gazete, 1992). 


\begin{tabular}{|c|c|c|}
\hline $13^{*}$ & DÍĞER AIACAKIAR & \\
\hline 131 & Ortaklaxdan Alacaklax & \\
\hline 132 & Iş̧tiraklexdem Alacaklax & \\
\hline 133 & Bağlı Ortaklıklardan Alacaklax & \\
\hline 135 & Personelden Alacaklax & \\
\hline 136 & Diğex Ceşitli Alacaklax & \\
\hline 137 & Diğex Alacak Senetleri Reeskomtu & $(-)$ \\
\hline 138 & Şiiplneli Diğex Alacaklax & \\
\hline 139 & Şuplheli Diğex Alacaklar Karşılığı & $(-)$ \\
\hline
\end{tabular}

TDHP 13* Diğer Alacaklar hesap grubuna ait 31 Aralık 20XX-1 tarihli bilgiler aşağıdaki gibidir.

\subsection{AC* Finans Sektörü Faaliyetlerinden Alacaklar Hesap Grubu}

\section{AE* İlişkili Taraflardan Ticari Alacaklar Hesap Grubu}

\section{$A F^{*}$ Diğer Alacaklar Hesap Grubu}

İlişkili taraf: Finansal tablolarını hazırlayan işletmeyle (bu Standartta "raporlayan işletme" olarak kullanılacaktır) ilişkili olan kişi veya işletmedir (TMS24Md.9, 2017).

İlişkili tarafla yapılan işlem: Raporlayan işletme ile ilişkili bir taraf arasında kaynakların, hizmetlerin ya da yükümlülüklerin, bir bedel karşılığı olup olmadığına bakılmaksızın transferidir (TMS24-Md.9, 2017).

Bir bireyin yakın aile üyeleri: İşletme ile ilgili işlemler üzerinde etkisi olması ya da işlemlerden etkilenmesi beklenen aile bireyleridir ve aşağıda belirtilenler bireyin yakın aile üyesi kapsamında yer alır:

(a) Bireyin eş ve çocukları,

(b) Bireyin eşinin çocukları ve

(c) Bireyin ya da bireyin eşinin bakmakla yükümlü olduğu kişiler (TMS24Md.9, 2017).

Kilit yönetici personel: İşletmenin, (idari ya da diğer) herhangi bir yöneticisi de dahil olmak üzere, faaliyetlerini plânlama, yönetme ve kontrol etme yetki ve sorumluluğuna doğrudan veya dolaylı olarak sahip olan kişilerdir (TMS24-Md.9, 2017).

Devlet: Devleti, devlet organlarını ve yerel, ulusal veya uluslararası benzer kuruluşları ifade eder. Devletle ilişkili işletme: Devletin, üzerinde kontrol veya müştereken kontrol gücüne ya da önemli etkiye sahip olduğu işletmedir (TMS24-Md.9, 2017).

İştirak: Yatırımcı işletmenin üzerinde önemli etkisinin bulunduğu işletmedir (TMS28-Md.3, 2017).

Müşterek kontrol: Bir anlaşma üzerindeki kontrolün sözleşmeye dayalı olarak paylaşılmasıdır. Bu kontrolün sadece, önemli konularla ilgili kararların, kontrolü paylaşan tarafların oy birliği ile mutabakatını gerektirdiği durumlarda var olduğu kabul edilir (TMS28-Md.3, 2017). 
İş ortaklı̆̆ı: müşterek kontrole sahip olan tarafların, girişimin net varlıkları üzerinde haklarının bulunduğu müşterek anlaşmadır (TMS28-Md.3, 2017).

\section{Önemli Etki}

Bir işletmenin doğrudan ya da dolaylı olarak (örneğin bağlı ortaklıkları vasıtasıyla) yatırım yapılan 3 işletmenin oy hakkının yüzde 20 ya da daha fazlasını elinde tutması durumunda, aksi açıkça ortaya konulamadığı sürece, söz konusu işletmenin önemli etkisinin bulunduğu kabul edilir. Diğer yandan, işletmenin doğrudan ya da dolaylı olarak (örneğin bağlı ortaklıkları vasıtasıyla) yatırım yapılan işletmenin oy hakkının yüzde 20'sinden daha azını elinde bulundurması durumunda ise; böyle bir etkinin bulunduğu açıkça ortaya konulamadığı sürece, söz konusu işletmenin önemli etkisinin bulunmadığ kabul edilir (TMS28-Md.5, 2017).

Diğer Alacaklar hesap grubu hesapları Şekil 1'de gösterilmiştir. (Erdoğan, 2012: 257)

\begin{tabular}{|c|c|c|c|c|}
\hline \multicolumn{3}{|c|}{ HESAP KODU } & \multirow{2}{*}{\begin{tabular}{|l} 
TFRS HESAP ADI \\
FİNANS SEKTÖORL̈̈ FAAL IIYETLERİNDEN ALACAKLAR
\end{tabular}} & \\
\hline A & C & E & & \\
\hline $\mathbf{A}$ & c & $\mathbf{A}$ & BANKACILIK FAALIYETLERINDDEN ALACAKLAR & \\
\hline A & C & $\mathbf{B}$ & SİGORTACILIK FAALİYETLERINDEN ALACAKLAR & \\
\hline $\mathbf{A}$ & C & C & FINANSAL KİRALAMA İŞLEMLERINDEN ALACAKLAR & \\
\hline $\mathbf{A}$ & C & $\mathbf{D}$ & FAKTORING FAALIYETLERINDEN ALACAKLAR & \\
\hline $\mathbf{A}$ & C & $\bar{E}$ & DIGGER FINANS SEKTÖRÜ FAALIYETLERI ALACAKLARI & \\
\hline $\mathbf{A}$ & C & $\mathbf{F}$ & FSF ERTELENMİȘ FINANSMAN KAZANCI & $(-)$ \\
\hline $\mathbf{A}$ & $\mathrm{C}$ & $\mathbf{G}$ & FSF SAYIM FARKLILIKLARI & $(+/-)$ \\
\hline $\mathbf{A}$ & c & $\mathbf{H}$ & FSF ȘÜPHELİ ALACAK KARȘILIĞI & $(-)$ \\
\hline $\mathbf{A}$ & E & $=$ & 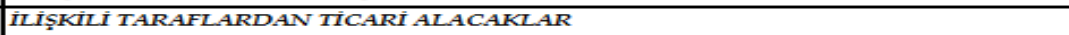 & \\
\hline $\mathbf{A}$ & E & $\mathbf{A}$ & ANA ORTAKLIKLARDAN ALACAKLAR & \\
\hline A & E & $\mathbf{B}$ & MÜȘTEREK KONTROL GÜCÜNE SAHIP BULUNAN IȘLETMELERDEN ALACAKLAR & \\
\hline A & E & C & ÖNEMLİ ETKİYE SAHIIP BULUNAN İȘLETMELERDEN ALACAKLAR & \\
\hline A & E & D & BAĞLI ORTAKLIKLARDAN ALACAKLAR & \\
\hline A & E & $\mathbf{E}$ & İSTTIRAKLERDEN ALACAKLAR & \\
\hline A & E & $\mathbf{F}$ & ORTAK GIRISTSIMCI OLAN ISS ORTAKLIKLARINDAN ALACAKLAR & \\
\hline $\mathbf{A}$ & E & G & İŞLETMENIN KİLITT YÖNETICII PERSONELINDEN ALACAKLAR & \\
\hline A & E & $\mathbf{H}$ & ANA ORTAKLIĞIN KILITT YÖNETICII PERSONELINDEN ALACAKLAR & \\
\hline $\mathbf{A}$ & E & I & DEVLETLE İLGILİ İȘLETMELERDEN ALACAKLAR & \\
\hline $\mathbf{A}$ & E & $\mathbf{J}$ & ORTAKLARDAN ALACAKLAR & \\
\hline $\mathbf{A}$ & E & $\mathbf{K}$ & ORTAKLARIN YAKIN AIILE ÜYELERINNDEN ALACAKLAR & \\
\hline $\mathbf{A}$ & E & $\mathbf{L}$ & TAZMINAT VERILLENLERDEN ALACAKLAR & \\
\hline $\mathbf{A}$ & E & $\mathbf{M}$ & PERSONELDEN ALACAKLAR & \\
\hline $\mathbf{A}$ & E & $\mathbf{N}$ & DİĞER İLISTKILII TARAFLARDAN ALACAKLAR & \\
\hline $\mathbf{A}$ & E & $\overline{0}$ & ILTA ERTELENMIȘ FINANSMAN KAZANCI & $(\rightarrow)$ \\
\hline A & E & $\mathbf{P}$ & ILLTA ŞÜPHELİ ALACAK KARȘILIĞII & $(\rightarrow)$ \\
\hline $\mathbf{A}$ & E & $\mathbf{R}$ & ILTA TIAL TAHAKKUKU & \\
\hline $\mathbf{A}$ & $\mathbf{F}$ & $=$ & DÍĞER ALACAKLAR & \\
\hline A & $\mathbf{F}$ & $\mathbf{B}$ & VERGİ DAİRELERINNDEN ALACAKLAR & \\
\hline $\mathbf{A}$ & $\mathbf{F}$ & C & $\begin{array}{l}\text { CARİ DÖNEM VERGISIYLE ILGILI VARLIKLAR DIȘINDAKİ KAMU İDARELERINDEN } \\
\text { ALACAKLAR }\end{array}$ & \\
\hline A & $\mathbf{F}$ & $\mathbf{D}$ & ILLIȘKILLI TARAFLARDAN DİG̈ER ALACAKLAR & \\
\hline $\mathbf{A}$ & $\mathbf{F}$ & $\mathbf{E}$ & DİG̈ER ÇEITTLİ ALACAKLAR & \\
\hline $\mathbf{A}$ & $\mathbf{F}$ & F & DIAAL ERTELENMISS FINANSMAN KAZANCI & $(-)$ \\
\hline $\mathbf{A}$ & $\mathbf{F}$ & $\mathbf{G}$ & DİAL ȘÜPHELİ ALACAK KARȘILIĞI & $(-)$ \\
\hline
\end{tabular}

Şekil 1. Finansal Durum Tablosu (Bilanço)'nun Diğer Alacaklar hesap grubu hesapları (Erdoğan, 2013). 


\section{Araştırmanın Bulguları}

\subsection{TDHP 13* Diğer Alacaklar Hesap Grubunun TFRS'lerin İlk Kez Uygulandığı Açılış Finansal Tablolarına Aktarılması}

\subsubsection{Senaryo}

$\checkmark$ BENO A.Ş. 'nin 01.01.2016 tarihli açllış bilançosu ve yevmiye kayıtlarına ilişkin veriler aşağıdadır.

100 KASA HS. $\quad 200.000 \mathrm{TL}$

102 BANKALAR HS. $\quad 100.000 \mathrm{TL}$

153 TİCARİ MALLAR HS. $130.000 \mathrm{TL}$

255 DEMIRBAŞLAR HS. $\quad 70.000 \mathrm{TL}$

500 SERMAYE HS. $\quad 500.000 \mathrm{TL}$

$\checkmark$ BENO A.Ş. güvenlik sistemleri üreten bir işletmedir. Bu işletme Dursun DURMAZ'ın \%8 hisse oranında ORTAĞI konumundadır. 31.08.2016 tarihinde ORTAK Dursun DURMAZ Kastamonu Daday ilçesindeki çiftlik evinin güvenliği için kamera sistemi kurmak amacıyla BENO A.Ş. den 100.000 TL + \%18 KDV tutarında kısa vadede bu tutarın ödenmek üzere kamera ve ekipman almıştır. Bu ekipmanın maliyeti 80.000 TL ve sürekli envanter yöntemi uygulanmaktadır. . Kısa vadeli bu alacağın 90 GÜNE KADAR ALACAĞI 80.000 TL, 91-365 GÜN ARASI ALACAĞI 20.000 TL dir. AĞIRLIKLI ORTALAMA FAİZ ORANI (YILLIK) \%10 ve AĞIRLIKLI ORTALAMA VADE (GÜN) 210 gündür. KDV tutarı ise 18.000 TL dir.

$\checkmark$ BENO A.Ş. MITEHA Ltd. Şti. nin \% 18 hisse oranında İŞTIRAK etmektedir.09.09.2016 tarihinde SGK denetimi sonucunda MITTEHA Ltd. Şti. 'ne 50.000 TL prim borcu tebliğ edilmiştir. 10.09.2016 tarihinde BENO A.Ş. MITEHA Ltd. Şti. ne 90 GÜNE KADAR VADELİ 40.000 TL, 91-365 GÜNE KADAR VADELİ 10.000 TL bankadan ödenmek üzere borç vermiştir. Bu alacağın AĞIRLIKLI ORTALAMA FAİZ ORANI (YILLIK) \% 8 ve AĞIRLIKLI ORTALAMA VADE (GÜN) 120 gündür.

BENO A.Ş. \%51 hisse oranında AZRA A.Ş. nin BAĞLI ORTAĞI konumundadır. AZRA A.Ş. BENO A.Ş. adına 100.000 TL kar payı dağıtacağını 01.10.2106 tarihinde ilan etmiştir. Bu kar payı alacağın 90 GÜNE KADAR ALACAĞI 75.000 TL, 91-365 GÜNE KADAR ALACAĞI 25.000 TL'dir. Bu alacağın AĞIRLIKLI ORTALAMA FAİZ ORANI (YILLIK) \% 5 ve AĞIRLIKLI ORTALAMA VADE (GÜN) 300 gündür.

BENO A.Ş. 15.10.2016 tarihinde şirketin CEO su (KİLİT PERSONEL YÖNETİCİ) olan Esra ALAN'a ev kredisi borcu için 30.000 TL nakit borç vermiştir. Bu borcun 90 GÜNE KADAR VADELİ 10.000 TL, 91-365 GÜNE KADAR VADELİ 20.000 TL'dir. Aynı tarihte şirketin Muhasebe-Finans departmanında çalışan muhasebeci Bay A (DİĞER PERSONEL) dikkatsizliği nedeniyle bir hafta önce satın alınarak şirketin envanterine kayıtlı 5.000 TL değerindeki bilgisayarı kullanılmaz hale getirmiş ve şirkete 90 GÜNE KADAR VADELİ 3.000 TL, 91- 
365 GÜNE KADAR VADELİ 2.000 TL borçlanmıştır. Bu alacağın AĞIRLIKLI ORTALAMA FAİZ ORANI (YILLIK) \% 2 ve AĞIRLIKLI ORTALAMA VADE (GÜN) 150 gündür.

$\checkmark$ BENO A.Ş. yakın ilişkiler içinde olduğu RSL Limited Şirketine 25.10.2016 tarihinde kısa vadeli olarak 72.000 TL hatır senedi vermiştir. Bu alacağın, 90 GÜNE KADAR VADELİ 50.000 TL, 91-365 GÜNE KADAR VADELİ 22.000 TL olup, AĞIRLIKLI ORTALAMA FAİZ ORANI (YILLIK) \% 3 ve AĞIRLIKLI ORTALAMA VADE (GÜN) 330 gündür.

$\checkmark$ 30.10.2016 tarihinde, BENO A.Ş. ORTAĞI Dursun DURMAZ dan 8.000 TL, İŞTIRAKİ olan MITTEHA Ltd. Şti den 10.000 TL, BAĞLI ORTAĞI AZRA A.Ş. den 15.000 TL, Şirketin CEO su (KİİT PERSONEL YÖNETICİ) Esra ALAN'dan $5.000 \mathrm{TL}$, hatır senedi verilen RSL Ltd. Şti. den $2.000 \mathrm{TL}$ olan alacakları vadesinde ödeme süresi geçmiş ve dava takibine başlatılmıştır. Bu alacakları şüpheli alacaklara dönüşmüştür.

$\checkmark$ BENO A.Ş. 01.11.2016 tarihinde 20.000 TL değerindeki üretimde kullandığı hurda makineyi \% 18 KDV ile 3 ay vadeli senet ile satmış ve KDV tutarı peşin almıştır. Şirkete 3 ay vadede sabit olmak üzere 1.000 TL faiz ödenmiştir. Bu işlem için dönem sonunda (31.12.2016) 1.000 TL reeskont hesaplanmıştır.

$\checkmark$ BENO A.Ş. 'nin ORTAĞI Dursun DURMAZ'dan olan 8.000 TL kısa vadeli alacağ 1 için dönem sonunda (31.12.2016) karşılık ayrılmıştır. Dava takibinde olan bu alacağı için KANUNEN KABUL EDİLEN GIDER tutarı 5.000. TL, KANUNEN KABUL EDILMEYEN GIDER tutarı ise 3.000 TL olarak hesaplanmıştır.

$\checkmark$ Dönem sonu işletmenin kapatma hesaplarını yapınız. 
2.1.2. TDHP Diğer Alacaklar Hesap Grubu Senaryo Yevmiye Kayıtları

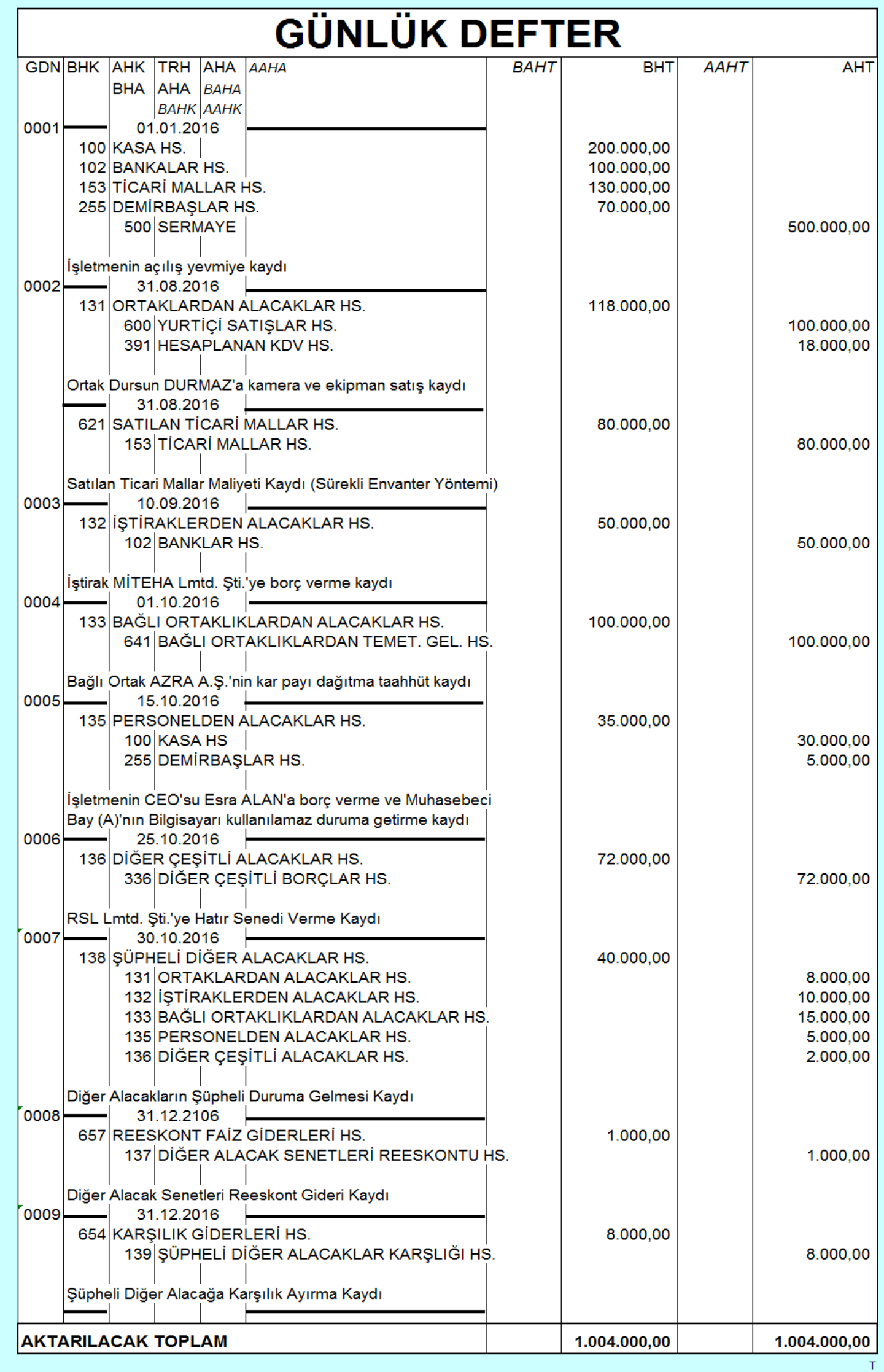




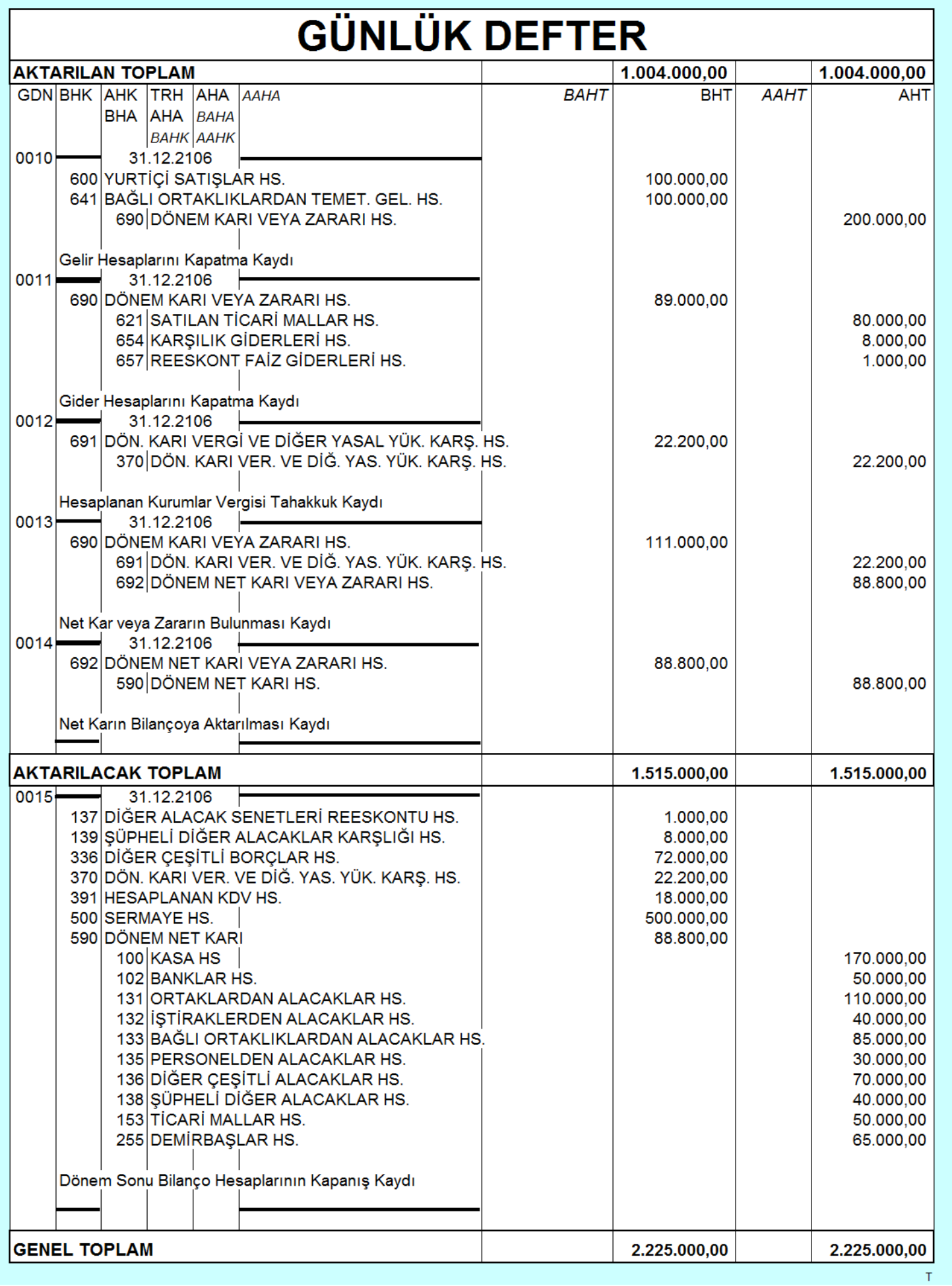

TDHP 13* Diğer Alacaklar hesap grubunun TFRS'lerin ilk kez uygulandığ 1 Açılış Finansal Tablolarına aktarılması amacıyla oluşturulan senaryoya ilişkin bilgilerin dönem içi yevmiye kayıtları ile dönem sonu gelir- gider hesaplarının kapatılması, \% 20 oranında Dönem Karından Dönem Karı Vergi ve Yasal Yükümlülükler Karşılığı ayrılması, Dönem Net Karı yevmiye kayıtlarının yapılması ve sonucunda Dönem Sonu Bilanço hesaplarının kapanış kayıtları yukarıdaki yevmiye kayıtlarında gösterilmiştir. 


\subsubsection{TDHP Diğer Alacaklar Hesap Grubu Senaryo Geçici Mizanı}

\begin{tabular}{|c|c|c|c|c|c|}
\hline \multicolumn{6}{|c|}{ BENO ANONIM ŞIRKETINIIN } \\
\hline \multicolumn{2}{|l|}{ HESAP } & \multicolumn{2}{|l|}{ TOPLAMLAR } & \multicolumn{2}{|l|}{ KALANLAR } \\
\hline KODU & $\mathrm{ADI}$ & BORC & ALACAK & BORC & ALACAK \\
\hline 100 & KASA HS. & $200.000,00$ & $30.000,00$ & $170.000,00$ & 0,00 \\
\hline 102 & BANKALAR HS. & $100.000,00$ & $50.000,00$ & $50.000,00$ & 0,00 \\
\hline 131 & ORTAKLARDAN ALACAKLAR HS. & $118.000,00$ & $8.000,00$ & $110.000,00$ & 0,00 \\
\hline 132 & İȘTiRAKLERDEN ALACAKLAR HS. & $50.000,00$ & $10.000,00$ & $40.000,00$ & 0,00 \\
\hline 133 & BAĞLI ORTAKLIKLARDAN ALACAKLAR HS. & $100.000,00$ & $15.000,00$ & $85.000,00$ & 0,00 \\
\hline 135 & PERSONELDEN ALACAKLAR HS. & $35.000,00$ & $5.000,00$ & $30.000,00$ & 0,00 \\
\hline 136 & \begin{tabular}{|l|} 
DIĞER ÇEȘiTLİ ALACAKLAR HS. \\
\end{tabular} & $72.000,00$ & $2.000,00$ & $70.000,00$ & 0,00 \\
\hline 137 & DIGGER ALACAK SENETLERI REESKON. HS.(- & & $1.000,00$ & 0,00 & $1.000,00$ \\
\hline 138 & ȘÜPHELİ DİĞER ALACAKLAR HS. & $40.000,00$ & & $40.000,00$ & 0,00 \\
\hline 139 & ȘÜPHELİ DIĞ. ALACAKLAR KARȘILIĞI HS.(-) & & $8.000,00$ & 0,00 & $8.000,00$ \\
\hline 153 & TICARI MALLAR HS. & $130.000,00$ & $80.000,00$ & $50.000,00$ & 0,00 \\
\hline 255 & DEMIRBAȘLAR HS. & $70.000,00$ & $5.000,00$ & $65.000,00$ & 0,00 \\
\hline 336 & DİĞER ÇEȘiTLİ BORÇLAR HS. & & $72.000,00$ & 0,00 & $72.000,00$ \\
\hline 391 & HESAPLANAN KDV HS. & & $18.000,00$ & 0,00 & $18.000,00$ \\
\hline 500 & SERMAYE HS. & & $500.000,00$ & 0,00 & $500.000,00$ \\
\hline 600 & YURT İCi SATIȘLAR HS. & & $100.000,00$ & 0,00 & $100.000,00$ \\
\hline 621 & SATILAN TICARI MALLAR HS. & $80.000,00$ & & $80.000,00$ & 0,00 \\
\hline 641 & BAĞLI ORTAK. TEMETTÜ GELIRLERİ HS. & & $100.000,00$ & & $100.000,00$ \\
\hline 654 & KARȘILIK GIDERLERİ HS. & $8.000,00$ & & $8.000,00$ & 0,00 \\
\hline 657 & REESKONT FAİZ GIDERLERİ HS. & $1.000,00$ & & $1.000,00$ & 0,00 \\
\hline TOPLAM & & $1.004 .000,00$ & $1.004 .000,00$ & $799.000,00$ & $799.000,00$ \\
\hline
\end{tabular}

\subsubsection{TDHP Diğer Alacaklar Hesap Grubu Senaryo Kesin Mizanı}

\begin{tabular}{|c|c|c|c|c|c|}
\hline \multicolumn{6}{|c|}{ BENO ANONIM ŞİRKETINİN } \\
\hline \multicolumn{2}{|l|}{ HESAP } & \multicolumn{2}{|c|}{ TOPLAMLAR } & \multicolumn{2}{|c|}{ KALANLAR } \\
\hline KODU & $\mathrm{ADI}$ & BORC & ALACAK & BORC & ALACAK \\
\hline 100 & KASA HS. & $200.000,00$ & $30.000,00$ & $170.000,00$ & 0,00 \\
\hline 102 & BANKALAR HS. & $100.000,00$ & $50.000,00$ & $50.000,00$ & 0,00 \\
\hline 131 & ORTAKLARDAN ALACAKLAR HS. & $118.000,00$ & $8.000,00$ & $110.000,00$ & 0,00 \\
\hline 132 & ISSTTiRAKLERDEN ALACAKLAR HS. & $50.000,00$ & $10.000,00$ & $40.000,00$ & 0,00 \\
\hline 133 & BAĞLI ORTAKLIKLARDAN ALACAKLAR HS. & $100.000,00$ & $15.000,00$ & $85.000,00$ & 0,00 \\
\hline 135 & PERSONELDEN ALACAKLAR HS. & $35.000,00$ & $5.000,00$ & $30.000,00$ & 0,00 \\
\hline 136 & DiĞER ÇEȘiTLİ ALACAKLAR HS. & $72.000,00$ & $2.000,00$ & $70.000,00$ & 0,00 \\
\hline 137 & DIĞER ALACAK SENETLERI REESKON. HS.(-) & & $1.000,00$ & 0,00 & $1.000,00$ \\
\hline 138 & ȘÜPHELI DIĞER ALACAKLAR HS. & $40.000,00$ & & $40.000,00$ & 0,00 \\
\hline 139 & ȘÜPHELI DIĞ. ALACAKLAR KARȘILIĞI HS.(-) & & $8.000,00$ & 0,00 & $8.000,00$ \\
\hline 153 & TiCARI MALLAR HS. & $130.000,00$ & $80.000,00$ & $50.000,00$ & 0,00 \\
\hline 255 & DEMIRBAȘLAR HS. & $70.000,00$ & $5.000,00$ & $65.000,00$ & 0,00 \\
\hline 336 & DiĞER ÇEȘiTLI BORCLLAR HS. & & $72.000,00$ & 0,00 & $72.000,00$ \\
\hline 370 & DÖNEM KARI VERGI VE DIĞER YASAL YÜK. KARȘILIĞ| & & $22.200,00$ & 0,00 & $22.200,00$ \\
\hline 391 & HESAPLANAN KDV HS. & & $18.000,00$ & 0,00 & $18.000,00$ \\
\hline 500 & SERMAYE HS. & & $500.000,00$ & 0,00 & $500.000,00$ \\
\hline 590 & DÖNEM NET KARI & & $88.800,00$ & 0,00 & $88.800,00$ \\
\hline 600 & YURT IÇi SATIȘLAR HS. & $100.000,00$ & $100.000,00$ & 0,00 & 0,00 \\
\hline 621 & SATILAN TICARI MALLAR HS. & $80.000,00$ & $80.000,00$ & 0,00 & 0,00 \\
\hline 641 & BAĞLI ORTAK. TEMETTÜ GELIRLERI HS. & $100.000,00$ & $100.000,00$ & 0,00 & 0,00 \\
\hline 654 & KARȘILIK GIDERLERI HS. & $8.000,00$ & $8.000,00$ & 0,00 & 0,00 \\
\hline 657 & REESKONT FAIZ GIDERLERI HS. & $1.000,00$ & $1.000,00$ & 0,00 & 0,00 \\
\hline 690 & DÖNEM KARI VEYA ZARARI & $200.000,00$ & $200.000,00$ & 0,00 & 0,00 \\
\hline 691 & DÖNEM KARI VERGI VE DIG̈ER YASAL YÜK. KARȘILIĞ| & $22.200,00$ & $22.200,00$ & 0,00 & 0,00 \\
\hline 692 & DÖNEM NET KARI VEYA ZARARI & $88.800,00$ & $88.800,00$ & 0,00 & 0,00 \\
\hline TOPLAM & & $1.515 .000,00$ & $1.515 .000,00$ & $710.000,00$ & $710.000,00$ \\
\hline
\end{tabular}

TDHP 13* Diğer Alacaklar hesap grubunun TFRS'lerin ilk kez uygulandığ Açılış Finansal Tablolarına aktarılması amacıyla oluşturulan senaryo sonucunda Büyük Defterde yer alan bilgilerin Dönem Sonu Geçici ve Kesin Sağlama Tablolarına aktarılarak Borç-Alacak dengesi sağlanmıştır. 


\subsubsection{TDHP Diğer Alacaklar Hesap Grubu Senaryo Gelir Tablosu}

\begin{tabular}{|c|c|c|c|c|}
\hline \multicolumn{5}{|c|}{ BENO ANONIM ŞIRKETININN 01.01.2016 - 31.12.2016 TARİHLI GELİR TABLOSU } \\
\hline & & & \multicolumn{2}{|c|}{ CARI DÖNEM } \\
\hline & & & & \\
\hline \multirow[t]{4}{*}{60} & \multicolumn{2}{|c|}{ BÜRÜT SATIŞLAR } & $100.000,00$ & \\
\hline & \multicolumn{2}{|c|}{600 Yurtici Satıslar } & $100.000,00$ & \\
\hline & 601 & Yurtdısı Satıšlar & 0,00 & \\
\hline & \multicolumn{2}{|c|}{602 Diğer Gelirler } & 0,00 & \\
\hline \multirow[t]{5}{*}{61} & \multicolumn{2}{|c|}{ SATIS INDIRIMLERI (-) } & & \\
\hline & \multicolumn{2}{|c|}{610 Satıștan ladeler (-) } & 0,00 & \\
\hline & \multicolumn{2}{|c|}{611 Satıs iskontoları (-) } & 0,00 & \\
\hline & \multicolumn{2}{|c|}{612 Diğer indirimler $(-)$} & 0,00 & \\
\hline & \multicolumn{2}{|c|}{ NET SATISLAR } & & $100.000,00$ \\
\hline \multirow[t]{6}{*}{62 . } & \multicolumn{2}{|c|}{ SATIŞLARIN MALIYETI (-) } & $80.000,00$ & \\
\hline & 620 & Satılan Mamüller Maliyeti $(-)$ & 0,00 & \\
\hline & 621 & Satulan Ticari Mallar Maliyeti $(-)$ & $80,000,00$ & \\
\hline & 622 & Satılan Hizmet Maliyeti $(-)$ & 0,00 & \\
\hline & 623 & Diğer Satışların Maliyeti (-) & 0,00 & \\
\hline & BRÜT SAT & IIŞ KÂRI VEYA ZARARI & & $20.000,00$ \\
\hline \multirow[t]{5}{*}{63} & \multicolumn{2}{|c|}{ FAALIYET GIDERLERI (-) } & 0,00 & \\
\hline & 630 & Araștırma ve Geliștirme Giderleri (-) & 0,00 & \\
\hline & 631 & Pazarlama, Satıs ve Dağitım Giderleri (-) & 0,00 & \\
\hline & 632 & Genel Yönetim Giderleri (-) & 0,00 & \\
\hline & FAALIYET & KÂRI VEYA ZARARI & & $20.000,00$ \\
\hline 64 & DIG̈ER FAAL & IYETLERDEN OLAĞAN GELIR VE KÂRLAR & $100.000,00$ & \\
\hline & 640 & istiraklerden Temettü Gelirleri & 0,00 & \\
\hline & 641 & Bağlı Ortaklıklardan Temettū Gelirleri & $100.000,00$ & \\
\hline & 642 & Faiz Gelirleri & $\quad 0,00$ & \\
\hline & 643 & Komisyon Gelirleri & 0,00 & \\
\hline & 644 & Konusu Kalmayan Karsillklar & 0,00 & \\
\hline & 645 & Menkul Krymet Satıs Kârları & 0,00 & \\
\hline & 646 & Kambiyo Kârları & 0,00 & \\
\hline & 647 & Reeskont Faiz Gelirleri & 0,00 & \\
\hline & 648 & Enflasyon Düzeltmesi Karları & 0,00 & \\
\hline & 649 & Diğer Olağan Gelir ve Kârlar & 0,00 & \\
\hline 65 & DIĞER FAAL & YYETLERDEN OLAĞAN GIDER VE ZARARLAR (-) & $9.000,00$ & \\
\hline & 653 & Komisyon Giderleri $(-)$ & 0,00 & \\
\hline & 654 & Karsillk Giderleri $(-)$ & $8.000,00$ & \\
\hline & 655 & Menkul Krymet Satıs Zararları (-) & 0,00 & \\
\hline & 656 & Kambiyo Zararları $(-)$ & 0,00 & \\
\hline & 657 & Reeskont Faiz Giderleri $(-)$ & $1.000,00$ & \\
\hline & 658 & Enflasyon Düzeltmesi Zararları (-) & 0,00 & \\
\hline & 659 & Diğer Olağan Gider ve Zararlar (-) & 0,00 & \\
\hline 66 & FINANSMAN & GIDERLERI (-) & 0,00 & \\
\hline & 660 & Kisa Vadeli Borclanma Giderleri $(-)$ & 0,00 & \\
\hline & 661 & Uzun Vadeli Borclanma Giderleri (-) & 0,00 & \\
\hline & OLAĞAN r & KÂR VEYA ZARAR & & $111.000,00$ \\
\hline 67 & OLAĞAN DIS & SII GELIR VE KÂRLAR & 0,00 & \\
\hline & 671 & Önceki Dönem Gelir ve Kârları & 0,00 & \\
\hline & 679 & Diğer Olağandısı Gelir ve Kârlar & 0,00 & \\
\hline 68 & OLAĞAN DIS & ŞI GIDER VE ZARARLAR (-) & 0,00 & \\
\hline & 680 & Calısmayan Kısım Gider ve Zararları (-) & 0,00 & \\
\hline & 681 & Ōnceki Dönem Gider ve Zararları (-) & 0,00 & \\
\hline & 689 & Diğer Olağandısı Gider ve Zararlar (-) & 0,00 & \\
\hline 69 & DÖNEM NET & KARI (ZARARI) & $88.800,00$ & \\
\hline & 690 DÖNEM & KÂRI VEYA ZARARI & $111.000,00$ & \\
\hline & 691 DÖNEM & KÂRI VERGI VE DIGGER YASAL YÜKÜM.KARŞ.(-) & $22.200,00$ & \\
\hline & 692 DÖNEM & NET KÂRI VEYA ZARARI & & $88.800,00$ \\
\hline
\end{tabular}

TDHP 13* Diğer Alacaklar hesap grubunun TFRS'lerin ilk kez uygulandığı Açılış Finansal Tablolarına aktarılması amacıyla oluşturulan senaryo sonucunda Gelir tablosu oluşturulmuştur. Oluşturulan Gelir Tablosu sonucunda da 88.800,00 TL Dönem Net Karına ulaşılmıştır. 


\subsubsection{TDHP Diğer Alacaklar Hesap Grubu Senaryo Bilanço Tablosu}

\begin{tabular}{|c|c|c|c|c|c|c|c|c|c|}
\hline \multicolumn{10}{|c|}{ BENO ANONIM ȘIRKETINİN 31.12.2016 TARİHLI AYRINTILI BİLANÇOSU } \\
\hline & & \multicolumn{3}{|c|}{ Cari Dönem } & & & \multicolumn{3}{|c|}{ Cari Dönem } \\
\hline 1 & DÖNEN VARLIKLAR & & & $636.000,00$ & 3 & KISA VADELI YABANCI KAYNAKLAR & & & $112.200,00$ \\
\hline 10 & Hazır Değerler & & $220.000,00$ & & 30 & Mali Borçlar & & 0,00 & \\
\hline 100 & Kasa & $170.000,00$ & & & 32 & Ticari Borçlar & & 0,00 & \\
\hline 101 & Alinan Çekler & 0,00 & & & 320 & Satcolar & 0,00 & & \\
\hline 102 & Bankalar & $50.000,00$ & & & 321 & Borç Senetleri & 0,00 & & \\
\hline 103 & Verilen Çekler ve Ödeme Emir.(-) & 0,00 & & & 322 & Borç Senetleri Reeskontu (-) & 0,00 & & \\
\hline 11 & Menkul Krymetler & & 0,00 & & 326 & Alinan Depozito ve Teminattar & 0,00 & & \\
\hline 12 & Ticari Alacaklar & & 0,00 & & 329 & Diğer Ticari Borçlar & 0,00 & & \\
\hline 120 & Alicalar & 0,00 & & & 33 & Diğer Borçlar & & $72.000,00$ & \\
\hline 121 & Alacak Senetteri & 0,00 & & & 331 & Ortaklara Borçlar & 0,00 & & \\
\hline 13 & Diğer Alacaklar & & $366.000,00$ & & 332 & İştiraklere Borçlar & 0,00 & & \\
\hline 131 & Ortaklardan Alacaklar & $110.000,00$ & & & 333 & Bağı Ortakklklara Borçlar & 0,00 & & \\
\hline 132 & İştiraklerden Alacaklar & $40.000,00$ & & & 335 & Personele Borçlar & 0,00 & & \\
\hline 133 & Bağılı Ortakklklardan Alacaklar & $85.000,00$ & & & 336 & Diğer Çeșiti Borçlar & $72.000,00$ & & \\
\hline 135 & Personelden Alacaklar & $30.000,00$ & & & 337 & Diğer Borç Senetleri Reeskontu (-) & 0,00 & & \\
\hline 136 & Diğer Çeșiti Alacaklar & $70.000,00$ & & & 34 & Alinan Avanslar & & 0,00 & \\
\hline 137 & Diğer Alacak Senetleri Reesk. $(-)$ & $1.000,00$ & & & 35 & Yıllara Yaygın İnş. Ve On. Hak. & & 0,00 & \\
\hline 138 & Şüpheli Diğer Alacaklar & $40.000,00$ & & & 36 & Ödenecek Vergi ve Diğer Yüküm. & & 0,00 & \\
\hline 139 & Şüpheli Diğer Alacaklar Karşıliğı (-) & $8.000,00$ & & & 360 & Ödenecek Vergi ve Fonları & 0,00 & & \\
\hline 15 & Stoklar & & $50.000,00$ & & 361 & Ödenecek Sosyal Güvenlik Kesintileri & 0,00 & & \\
\hline 150 & İk Madde ve Malzeme & 0,00 & & & 368 & Vadesi Geçmiş Ert. veya Taksitendirilmiş & 0,00 & & \\
\hline 151 & Yarı Mamüller & 0,00 & & & & Vergi ve Diğer Yükümlülükler & 0,00 & & \\
\hline 152 & Mamüller & 0,00 & & & 369 & Ödenecek Diğer Yükümlü̈lükler & 0,00 & & \\
\hline 153 & Ticari Mallar & $50.000,00$ & & & 37 & Borç ve Gider Karşılıkları & & $22.200,00$ & \\
\hline 17 & Yillara Yaygın İns. Ve On. Mal. & & 0,00 & & 370 & Dönem Karı Vergi ve Diğer & $22.200,00$ & & \\
\hline 18 & Gel. Ayl. Ait Gid. Ve Gelir Tah. & & 0,00 & & & Yasal Yükümlülük Karşllkları & & & \\
\hline 19 & Diğer Dönen Varlıklar & & 0,00 & & 371 & Dönem Karinin Peşin Ödenen Vergi & 0,00 & & \\
\hline \multirow{2}{*}{191} & İndirlecek KDV & 0,00 & & & & ve Diğer Yükümlülükleri (-) & & & \\
\hline & DÖNEN VARLIKLAR TOPLAMI & & & $636.000,00$ & 372 & Kidem Tazminat Karşliğı & 0,00 & & \\
\hline 2 & DURAN VARLIKLAR & & & $65.000,00$ & 373 & Maliyet Giderleri Karşılığı & 0,00 & & \\
\hline 22 & Ticari Alacaklar & & 0,00 & & 379 & Diğer Borç ve Gider Karșllkkarı & 0,00 & & \\
\hline 23 & Diğer Alacaklar & & 0,00 & & 38 & Gelecek Aylara Ait Gelirler ve Gider & & 0,00 & \\
\hline 24 & Mali Duran Varlıklar & & 0,00 & & & Tahakkukları & & & \\
\hline 240 & Bağı Menkul Kyymetter & 0,00 & & & 39 & Diğer Kısa Vadeli Yabancı Kaynaklar & & $18.000,00$ & \\
\hline \multirow[t]{2}{*}{241} & Bağl Menkul Kıymetler Değer & 0,00 & & & 391 & Hesaplanan KDV & $18.000,00$ & & \\
\hline & Düșüküüğ Karşılı̆ı (-) & & & & 392 & Diğer KDV & 0,00 & & \\
\hline 242 & İștirakler & 0,00 & & & 393 & Merkez Ve Şubeler Cari Hesabı & 0,00 & & \\
\hline 243 & İștiraklere Sermaye Taahhütteri (-) & 0,00 & & & 397 & Sayim ve Tesellüm Fazlaları & 0,00 & & \\
\hline \multirow[t]{2}{*}{244} & İștiakler Sermaye Payları Değer & 0,00 & & & 399 & Diğer Çeșitil Yabana Kaynaklar & 0,00 & & \\
\hline & Değer Düşükü̆ğü Karşılı̆̆ (-) & & & & & KISA VADEL̇ YABANCI & & & $112.200,00$ \\
\hline 245 & Bağlı Ortakklklar & 0,00 & & & & KAYNAKLAR TOPLAMI & & & \\
\hline \multirow[t]{2}{*}{246} & Bağı Ortaklklara Sermaye & 0,00 & & & 4 & UZUN VADELI YABANCI KAYNAKLAR & & & 0,00 \\
\hline & Taahhütleri (-) & & & & 40 & Mali Borçlar & & 0,00 & \\
\hline \multirow[t]{2}{*}{247} & Bağı Ortakllklar Sermaye Payları & 0,00 & & & 42 & Ticari Borçlar & & 0,00 & \\
\hline & Değer Düșükü̆ğü Karşilğı̆ (-) & & & & 43 & Diğer Borçlar & & 0,00 & \\
\hline 249 & Diğer Mali Duran Varlkklar Karşsliğı (-) & 0,00 & & & 44 & Alınan Avanslar & & 0,00 & \\
\hline 25 & Maddi Duran Varlıklar & & $65.000,00$ & & 47 & Borç ve Gider Karşılıkları & & 0,00 & \\
\hline 250 & Arazi ve Arsalar & 0,00 & & & 48 & Gelecek Yillara Ait Gelirler ve & & 0,00 & \\
\hline 251 & Yeralt ve Yerüstü Düzenleri & 0,00 & & & & Gider Tahakkukları & & & \\
\hline 252 & Binalar & 0,00 & & & 49 & Diğer Uzun Vadeli Yabancı Kaynaklar & & 0,00 & \\
\hline 253 & Tesis, Makine ve Cihazlar & 0,00 & & & & UZUN VADEL̇ YABANCI & & & 0,00 \\
\hline 254 & Taşitlar & 0,00 & & & & KAYNAKLAR TOPLAMI & & & \\
\hline 255 & Demirbașlar & $65.000,00$ & & & 5 & ÖZKAYMAKLAR & & & $588.800,00$ \\
\hline 256 & Diğer Maddi Duran Varliklar & 0,00 & & & 50 & Ödenmiş Sermaye & & $500.000,00$ & \\
\hline 257 & Birikmiş Amortismanlar (-) & 0,00 & & & 500 & Sermaye & $500.000,00$ & & \\
\hline 26 & Maddi Olmayan Duran Varlıklar & & 0,00 & & 501 & Ödenmemiş Sermaye $(-)$ & 0,00 & & \\
\hline 27 & Özel Tükenmeye Tabi Varlıklar & & 0,00 & & 52 & Sermaye Yedekleri & & 0,00 & \\
\hline 271 & Arama Giderleri & 0,00 & & & 54 & Kar Yedekleri & & 0,00 & \\
\hline 272 & Hazrllk ve Geliştirme Giderleri & 0,00 & & & 57 & Geçmiş Yıllar Karları & & 0,00 & \\
\hline 277 & Diğer Özel Tükenmeye Tabi Varliklar & 0,00 & & & 570 & Geçmiş Yillar Karları & 0,00 & & \\
\hline 278 & Birikmiş Tükenme Payları (-) & 0,00 & & & 58 & Geçmiş Yillar Zararları (-) & & 0,00 & \\
\hline 279 & Verilen Avanslar & 0,00 & & & 580 & Geçmiş Ylllar Zararları (-) & 0,00 & & \\
\hline 28 & Gelecek Yillara Ait Giderler ve & & 0,00 & & 59 & Dönem Net Karı (Zararı) & & $88.800,00$ & \\
\hline & Gelir Tahakkukları & & & & 590 & Dönem Net Karı & $88.800,00$ & & \\
\hline 29 & Diğer Duran Varlıklar & & 0,00 & & 591 & Dönem Net Zararı (-) & 0,00 & & \\
\hline & DURAN VARLIKLAR TOPLAMI & & & $65.000,00$ & & ÖZKAYNAKLAR TOPLAMI & & & $588.800,00$ \\
\hline & & & & & & & & & \\
\hline VAR & IKLAR TOPLAMI & & 0,00 & $701.000,00$ & KAYN & IAKLAR TOPLAMI & & 0,00 & $701.000,00$ \\
\hline & & & & & & & & & \\
\hline & AKTIF (VARLIKLAR) TOPLAMI & & 0,00 & $701.000,00$ & & PASIF KAYNAKLAR TOPLAMI & & 0,00 & $701.000,00$ \\
\hline
\end{tabular}

TDHP 13* Diğer Alacaklar hesap grubunun TFRS'lerin ilk kez uygulandiğ Açılış Finansal Tablolarına aktarılması amacıyla oluşturulan senaryo sonucunda Dönem Sonu Bilançosu oluşturulmuştur. Oluşturulan Dönem Sonu Bilançoda 701.000,00 TL ile Aktif-Pasif denkliği sağlanmıştır. 


\subsubsection{TDHP 13* Diğer Alacaklar Hesap Grubundan 131 Ortaklardan Alacaklar Hesab1}

31.12.20XX-1 tarihi itibariyle VUK'na göre düzenlenen Bilançoda 131 Ortaklardan Alacaklar hesap grubuna yönelik veriler şöyledir (MOMTOS, 2017).

131 ORTAKLARDAN ALACAKLAR

KV ORTAKI ARDAN ALACAKLAR (9O GUNE KADAR)

KV ORTAKLARDAN ALACAKIAR (91-365 GUN ARASI)

AGIRLIKLI ORTALAMA FAIZ ORANI YILLIK $(\%)$

KDV + OTV + DIGER VERGILER

131 Ortaklardan Alacaklar Hesabında Bulunan Tutarlara Yönelik Açıklamalar Şöyledir,

- $[$ KV ORTAKLARDAN ALACAKLAR(90 GÜNE KADAR)], KV ORTAKLARDAN ALACAKLAR (90 GÜNE KADAR),

- $[\mathrm{KV}$ ORTAKLARDAN ALACAKLAR (91-365GÜNE KADAR)], KV ORTAKLARDAN ALACAKLAR (91-365GÜNE KADAR),

- [AĞIRLIKLI ORTALAMA FAİZ ORANI YILLIK], AĞIRLIKLI ORTALAMA FAİZ ORANI YILLIK,

- [AĞIRLIKLI ORTALAMA VADE (GÜN)], AĞIRLIKLI ORTALAMA VADE (GÜN),

- [KDV+ÖTV+DİĞER VERGİLER\%], KDV+ÖTV+DİĞER VERGİLER\% olarak dikkate alınır.

\begin{tabular}{|l|r|}
\hline 131 ORTAKLARDAN ALACAKLAR & $\mathbf{1 1 0 , 0 0 0 . 0 0}$ \\
\hline AAE DİGR NNBV (90 gün içinde NAKDE ÇEVRİLEBILECEK) & $88,000.00$ \\
\hline AEJ ORTAKLARDAN ALACAKLAR & $22,000.00$ \\
\hline FIN VADE FARKI FINANSMAN KAYBI & -678.68 \\
\hline AEO ILTA ERTELENMISS FINANSMAN KAZANCI (-) & 678.68 \\
\hline
\end{tabular}

Şekil 2. Yeni TTK Çerçevesinde 131ORTAKLARDAN ALACAKLAR hesabının TFRS 1 'e Göre Açılış Finansal Tablolarına Aktarılması

- [KV ORTAKLARDAN ALACAKLAR(90 GÜNE KADAR)] olarak gösterilen 88.000TL tutar AAE DİĞER NNBV(90 GÜN İÇİNDE NAKDE ÇEVRILLEBILLECEK) hesabına,

- [KV ORTAKLARDAN

ALACAKLAR

(91-365GÜNE KADAR)]+[KDV+ÖTV+DİĞER VERGİLER] hesabiyla, 22.000 TL + 0TL = 22.000 TL olarak AEJORTAKLARDAN ALACAKLAR hesabina,

- [((KV ORTAKLARDAN ALACAKLAR (91-365GÜNE KADAR)/(1+(AĞIRLIKLI ORTALAMAFAİZ ORANI YILLIK/100) $)^{\wedge}(($ AĞIRLIKLI ORTALAMA VADE90)/365))-KV ORTAKLARDAN ALACAKLAR (91-365GÜNE KADAR) hesabiyla, $\left.\left.((22.000) /(1+10 / 100))^{\wedge}((210-90) / 365)\right)-22.000\right)=-678,68 \quad$ olarak $\quad$ FIN VADE FARKI FINANSMAN KAYBI hesabina,

- $\quad$ [(KV ORTAKLARDAN ALACAKLAR (91-365GÜNE KADAR)/(1+(AĞIRLIKLI ORTALAMAFAIZZ ORANI YILLIK/100) $)^{\wedge}(($ AĞIRLIKLI ORTALAMA VADE90)/365))-KV ORTAKLARDAN ALACAKLAR (91-365GÜNE KADAR)*(-1) hesabiyla, $\left.\left.((22.000) /(1+10 / 100))^{\wedge}((210-90) / 365)\right)-22.000\right)^{*}(-1)=678,68$ olarak AEO İLTA ERTELENMIŞFINANSMAN KAZANCI (-) hesabına aktarılmıştır.

VUK'tan TFRS'na Geçiş sürecinde bir DÜZELTME KAYDI yapıllmayacaktır. Ancak anlaşılırlığı arttırmak amacıyla aşağıdaki gibi bir YEVMIYY MADDESİ çalışma kâğıtlarında SAĞLAMA aracı olarak kullanılabilir. 


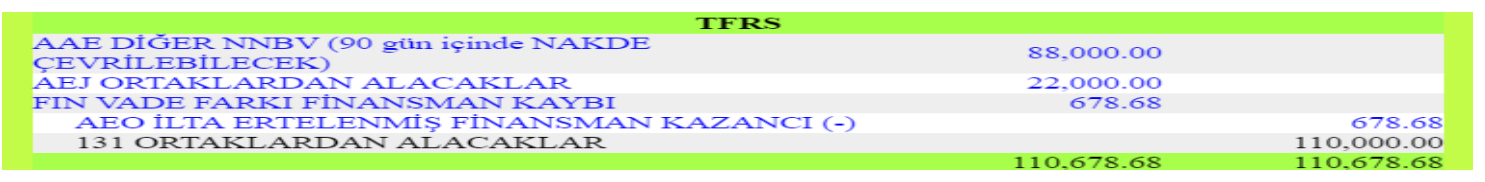

\subsubsection{TDHP 13* Diğer Alacaklar hesap grubundan 132 İştiraklerden Alacaklar Hesab1}

31.12.20XX-1 tarihi itibariyle VUK'na göre düzenlenen Bilançoda 132İştiraklerden Alacaklar hesabına yönelik veriler şöyledir (MOMTOS, 2017).

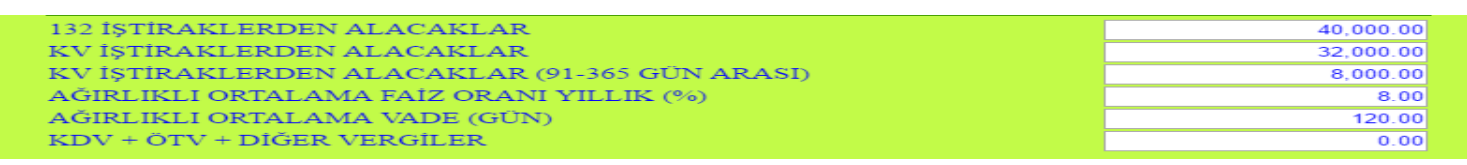

132 İştiraklerden Alacaklar Hesabında Bulunan Tutarlara Yönelik Açıklamalar Şöyledir,

[KV İSTTIRAKLERDEN ALACAKLAR(90 GÜNE KADAR)], KV İsTIIRAKLERDEN ALACAKLAR (90 GÜNE KADAR),

- $\quad$ [KV IŞTIIRAKLERDEN ALACAKLAR (91-365GÜNE KADAR)], KV İSTİRAKLERDEN ALACAKLAR (91-365GÜNE KADAR),

- [AĞIRLIKLI ORTALAMA FAİZ ORANI YILLIK], AĞIRLIKLI ORTALAMA FAİZ ORANI YILLIK,

- [AĞIRLIKLI ORTALAMA VADE (GÜN)], AĞIRLIKLI ORTALAMA VADE (GÜN),

- [KDV+ÖTV+DİĞER VERGİLER\%], KDV+ÖTV+DİĞER VERGİLER\% olarak dikkate alınır.

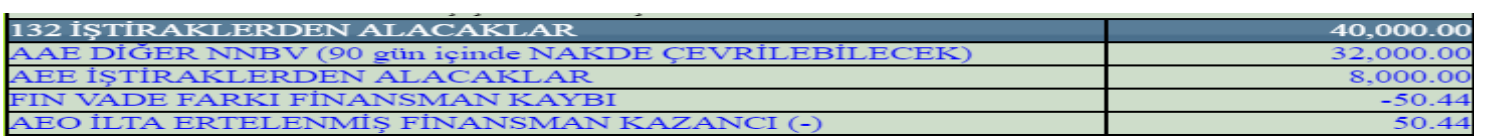

Şekil 3. Yeni TTK Çerçevesinde 132 İŞTİRAKLERDEN ALACAKLAR hesabının TFRS 1'e Göre Açılış Finansal Tablolarına Aktarılması

- [KV İSTTIRAKLERDEN ALACAKLAR(90 GÜNE KADAR)] olarak gösterilen 32.000TL tutar AAE DİĞER NNBV(90 GÜN İÇİNDE NAKDE ÇEVRILLEBİLECEK) hesabına,

- [KV İŞTIRAKLERDEN ALACAKLAR (91-365GÜNE KADAR)]+[KDV+ÖTV+DİĞER VERGİLER] hesabiyla, 8.000 TL + 0TL = 8.000 TL olarak AEE IŞTİRAKLERDEN ALACAKLAR hesabına,

- [((KV İsTIIRAKLERDEN ALACAKLAR (91-365GÜNE KADAR)/(1+(AĞIRLIKLI ORTALAMAFAİZ ORANI YILLIK/100)^((AĞIRLIKLI ORTALAMA VADE90)/365))-KV İSTIIRAKLERDEN ALACAKLAR (91-365GÜNE KADAR) hesabiyla, $\left.\left.((8.000) /(1+8 / 100))^{\wedge}((120-90) / 365)\right)-8.000\right)=-50,44$ olarak FIN VADE FARKI FINANSMAN KAYBI hesabina,

- [((KV İSTTIRAKLERDEN ALACAKLAR (91-365GÜNE KADAR)/(1+(AĞIRLIKLI ORTALAMAFAİZ ORANI YILLIK/100)^((AĞIRLIKLI ORTALAMA VADE90)/365))-KV İŞTIRAKLERDEN ALACAKLAR (91-365GÜNE KADAR)*(-1) hesabiyla, $\left.\left.((8.000) /(1+8 / 100))^{\wedge}((120-90) / 365)\right)-8.000\right)^{*}(-1)=50,44$ olarak AEO İLTA ERTELENMIŞFINANSMAN KAZANCI (-) hesabına aktarılmıştır. 
VUK'tan TFRS'na Geçiş sürecinde bir DÜZELTME KAYDI yapılmayacaktır. Ancak anlaşılırlığı arttırmak amacıyla aşağıdaki gibi bir YEVMİYE MADDESİ çalışma kâğıtlarında SAĞLAMA aracı olarak kullanılabilir.

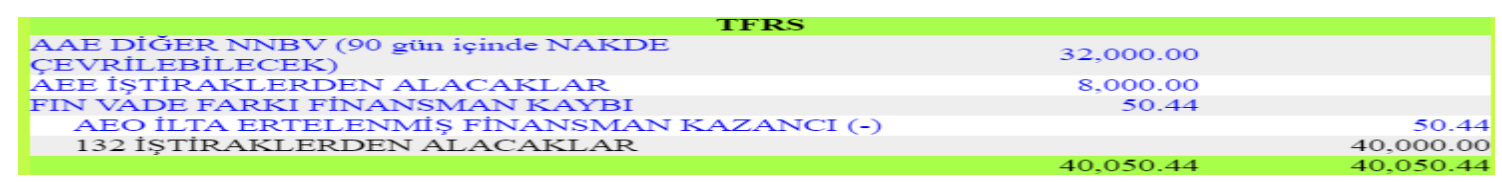

\subsubsection{TDHP $13^{*}$ Diğer Alacaklar hesap grubundan 133 Bağlı Ortaklıklardan Alacaklar Hesabi}

31.12.20XX-1 tarihi itibariyle VUK'na göre düzenlenen Bilançoda Bağl1 Ortaklıklardan Alacaklar hesap grubuna yönelik veriler şöyledir (MOMTOS, 2017).
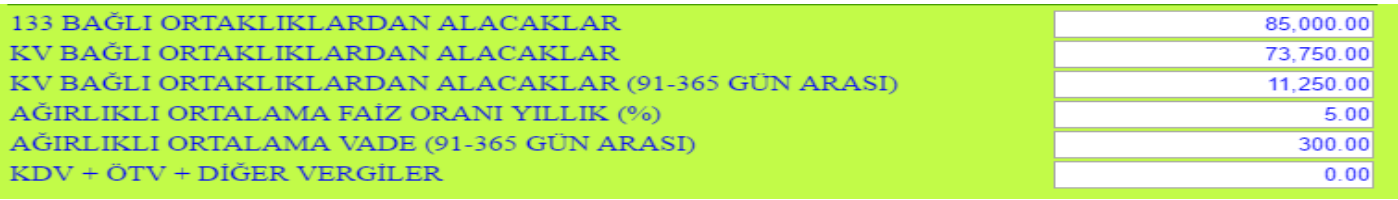

133 Bağlı Ortaklıklardan Alacaklar Hesabında Bulunan Tutarlara Yönelik Açıklamalar Şöyledir,

- [KV BAĞLI ORTAKLIKLARDAN ALACAKLAR(90 GÜNE KADAR)], KV BAĞLI ORTAKLIKLARDAN ALACAKLAR (90 GÜNE KADAR),

- [KV BAĞLI ORTAKLIKLARDAN ALACAKLAR (91-365GÜNE KADAR)], KV BAĞLI ORTAKLIKLARDAN ALACAKLAR (91-365GÜNE KADAR),

- [AĞIRLIKLI ORTALAMA FAİZ ORANI YILLIK], AĞIRLIKLI ORTALAMA FAIZZ ORANI YILLIK,

- [AĞIRLIKLI ORTALAMA VADE (GÜN)], AĞIRLIKLI ORTALAMA VADE (GÜN),

- [KDV+ÖTV+DİĞER VERGİLER\%], KDV+ÖTV+DİĞER VERGİLER\% olarak dikkate alınır.

\begin{tabular}{|l|r|}
\hline 133 BAGLI ORTAKLIKLARDAN ALACAKLAR & $\mathbf{8 5 , 0 0 0 . 0 0}$ \\
\hline AAE DÏGER NNBV (90 gün içinde NAKDE ÇVRİLEBİLECEK) & $73,750.00$ \\
\hline AED BAGLI ORTAKLIKLARDAN ALACAKLAR & $11,250.00$ \\
\hline FIN VADE FARKI FINANSMAN KAYBI & -311.41 \\
\hline AEO İTA ERTELENMIȘ FINANSMAN KAZANCI (-) & 311.41 \\
\hline
\end{tabular}

Şekil 4. Yeni TTK Çerçevesinde 133 BAĞLI ORTAKLIKLARDAN ALACAKLAR hesabının TFRS 1 'e Göre Açılış Finansal Tablolarına Aktarılması

- [KV BAĞLI ORTAKLIKLARDAN ALACAKLAR(90 GÜNE KADAR)] olarak gösterilen 73.750TL tutar AAE DİĞER NNBV(90 GüN İÇİNDE NAKDE ÇEVRILLBÍLECEK) hesabina,

- IKV BAĞLI ORTAKLIKLARDAN ALACAKLAR (91-365GÜNE KADAR)]+[KDV+ÖTV+DİĞER VERGİLER] hesabiyla, 11.250 TL + 0TL = 11.250 TL olarak AEDBAĞLI ORTAKLIKLARDAN ALACAKLAR hesabına,

- $\quad$ [(KV BAĞLI ORTAKLIKLARDAN ALACAKLAR (91-365GÜNE KADAR $) /(1+($ AĞIRLIKLI ORTALAMA FAIZ ORANI YILLIK/100) $)^{\wedge}(($ AĞIRLIKLI ORTALAMA VADE-90)/365))-KV BAĞLI ORTAKLIKLARDAN ALACAKLAR (91-365GÜNE KADAR) hesabiyla, $\left.\left.((11.250) /(1+5 / 100))^{\wedge}((300-90) / 365)\right)-11.250\right)=-311,41$ olarak FIN VADE FARKI FINANSMAN KAYBI hesabina, 
- $\quad$ [(KV BAĞLI ORTAKLIKLARDAN ALACAKLAR (91-365GÜNE KADAR $) /(1+($ AĞIRLIKLI ORTALAMA $\quad$ FAİZ ORANI YILLIK/100) $)^{\wedge}(($ AĞIRLIKLI ORTALAMA VADE-90)/365))-KV BAĞLI ORTAKLIKLARDAN ALACAKLAR (91-365GÜNE KADAR)*(-1) hesabiyla, $\left.\left.((11.250) /(1+5 / 100))^{\wedge}((300-90) / 365)\right)-11.250\right)^{*}(-1)=311,41 \quad$ olarak $\quad$ AEO ILTA ERTELENMIŞFINANSMAN KAZANCI (-) hesabına aktarılmıştır.

VUK'tan TFRS'na Geçiş sürecinde bir DÜZELTME KAYDI yapılmayacaktır. Ancak anlaşılırlığı arttırmak amacıyla aşağıdaki gibi bir YEVMİYE MADDESİ çalışma kâğıtlarında SAĞLAMA aracı olarak kullanılabilir.

\begin{tabular}{|c|c|c|}
\hline \multicolumn{3}{|l|}{ ה" } \\
\hline $\begin{array}{l}\text { AAE DİGER NNBV (90 gün içinde NAKDE } \\
\text { ÇEVRILEBİLECEK) }\end{array}$ & $73,750.00$ & \\
\hline AED BAĞLI ORTAKLIKLARDAN ALACAKLAR & $11,250.00$ & \\
\hline FIN VADE FARKI FINANSMAN KAYBI & 311.41 & \\
\hline AEO İLA ERTELENMISS FINANSMAN KAZANCI (-) & & 311.41 \\
\hline 133 BAĞLI ORTAKLIKLARDAN ALACAKLAR & & $85,000.00$ \\
\hline & $85,311.41$ & $85,311.41$ \\
\hline
\end{tabular}

\subsubsection{TDHP 13* Diğer Alacaklar hesap grubundan 135 Personelden Alacaklar Hesab1}

31.12.20XX-1 tarihi itibariyle VUK'na göre düzenlenen Bilançoda Personelden Alacaklar hesap grubuna yönelik veriler şöyledir (MOMTOS, 2017).

\begin{tabular}{l|r}
\hline 135 PERSONELDEN ALACAKLAR & $30,000.00$ \\
ISSLTMENIN KILIT YÖNETICI PERSONELINDEN ALACAKLAR (9O GUNE & $9,000.00$ \\
KADAR) & $3,000.00$ \\
DIGGER PERSONELDEN ALACAKLAR (9O GÜNE KADAR) \\
IŞLETMENIN KILIT YÖNETICI PERSONELINDEN ALACAKLAR (91-365 GÜN \\
ARASI) \\
DİGER PERSONELDEN ALACAKLAR (91-365 GÜN ARASI) \\
AĞIRLIKLI ORTALAMA FAIZ ORANI YILLIK (\%) \\
AĞIRLIKLI ORTALAMA VADE (91-365 GÜN ARASI) \\
KDV + ÖTV + DIGGER VERGILER
\end{tabular}

135 Personelden Alacaklar Hesabında Bulunan Tutarlara Yönelik Açıklamalar Şöyledir,

- [İŞLETMENIN KİLITT YÖNETİCI PERSONELINDENALACAKLAR(90 GÜNE KADAR)], ISSLETMENIN KİLIT YÖNETICİ PERSONELINDENALACAKLAR (90 GÜNE KADAR),

- [DİĞER PERSONELDEN ALACAKLAR (90 GÜNE KADAR)], DİĞER PERSONELDEN ALACAKLAR (90 GÜNE KADAR),

- [ISSLETMENIN KİLIT YÖNETICİ PERSONELINDENALACAKLAR(91365GÜNE KADAR)], İŞLETMENIN KILITT YÖNETICI PERSONELINDENALACAKLAR (91-365GÜNE KADAR),

- [DİĞER PERSONELDEN ALACAKLAR (91-365GÜNE KADAR)], DİĞER PERSONELDEN ALACAKLAR (91-365GÜNE KADAR),

- [AĞIRLIKLI ORTALAMA FAİZ ORANI YILLIK], AĞIRLIKLI ORTALAMA FAIZ ORANI YILLIK,

- [AĞIRLIKLI ORTALAMA VADE (GÜN)], AĞIRLIKLI ORTALAMA VADE (GÜN),

- [KDV+ÖTV+DİĞER VERGİLER\%], KDV+ÖTV+DİĞER VERGİLER\% olarak dikkate alınır. 


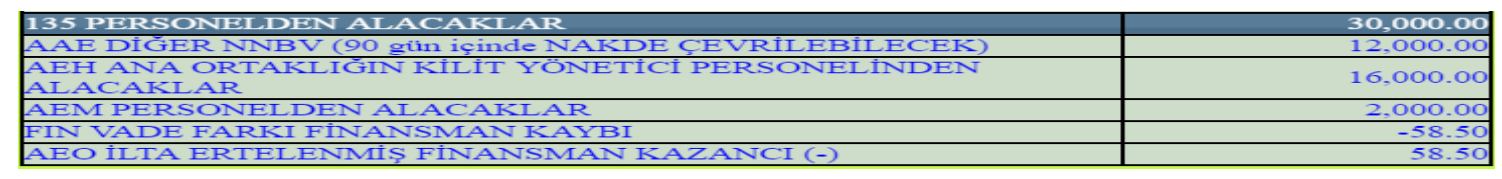

Şekil 5. Yeni TTK Çerçevesinde 135 PERSONELDEN ALACAKLAR hesabının TFRS 1 'e Göre Açılış Finansal Tablolarına Aktarılması

- [İŞLTMENIN KİLİT YÖNETICİ PERSONELINNDEN ALACAKLAR(90 GÜNE KADAR)]+ [DİĞER PERSONELDEN ALACAKLAR (90 GÜNE KADAR)] hesabiyla 9.000 TL + 3.000 TL=12.000 TL tutar AAE DİĞER NNBV(90 GÜN IÇİNDE NAKDE ÇEVRILEBILECEK) hesabına,

- [İŞLETMENIN KİLITT YÖNETICI PERSONELINDEN ALACAKLAR (91365GÜNE KADAR)] hesabiyla, 16.000 TL olarak AEH ANA ORTAKLIĞIN KILIIT YÖNETICİ PERSONELINDEN ALACAKLAR hesabina,

- [DİĞER PERSONELDEN ALACAKLAR (91-365GÜNE KADAR)]+ [KDV+ÖTV+DİĞER VERGİLER] hesabiyla,2.000 TL + 0 TL= 2.000 TL tutar AEM PERSONELDEN ALACAKLAR hesabina,

- $\quad$ [((KV İŞLETMENIN KİİT YÖNETICİ PERSONELINDEN ALACAKLAR (91365GÜNE KADAR + DİĞER PERSONELDEN ALACAKLAR (91-365GÜNE KADAR $) /(1+($ AĞIRLIKLI ORTALAMA FAIZ ORANI YILLIK/100)^^((AĞIRLIKLI ORTALAMA VADE-90)/365))-( KV İŞLETMENIN KILITT YÖNETICİ PERSONELINDEN ALACAKLAR (91-365GÜNE KADAR + DİĞER PERSONELDEN ALACAKLAR (91-365GÜNE KADAR)) hesabiyla, $\left.\left(((16.000+2.000) /(1+2 / 100))^{\wedge}((150-90) / 365)\right)-(16.000+2.000)\right)=-58,50$ olarak FIN VADE FARKI FINANSMAN KAYBI hesabina,

- $\quad$ [((KV İŞLETMENIN KİLIT YÖNETICİ PERSONELINDEN ALACAKLAR (91365GÜNE KADAR + DİĞER PERSONELDEN ALACAKLAR (91-365GÜNE KADAR $) /(1+($ AĞIRLIKLI ORTALAMA FAIZ ORANI YILLIK/100) $)^{\wedge}(($ AĞIRLIKLI ORTALAMA VADE-90)/365))-( KV İ̧̧LETMENIN KILITT YÖNETICII PERSONELINNDEN ALACAKLAR (91-365GÜNE KADAR + DİĞER PERSONELDEN ALACAKLAR (91-365GÜNE KADAR) $)^{*}(-1)$ hesabiyla, $\left.\left.((16.000+2.000) /(1+2 / 100))^{\wedge}((150-90) / 365)\right)-(16.000+2.000)\right)^{*}(-1)=58,50$ olarak AEO İLTA ERTELENMIŞFINANSMAN KAZANCI (-) hesabına aktarılmıştır.

VUK'tan TFRS'na Geçiş sürecinde bir DÜZELTME KAYDI yapılmayacaktır. Ancak anlaşılırlığı arttırmak amacıyla aşağıdaki gibi bir YEVMİYE MADDESİ çalışma kâğıtlarında SAĞLAMA aracı olarak kullanılabilir.

\begin{tabular}{|c|c|c|}
\hline \multicolumn{3}{|l|}{ 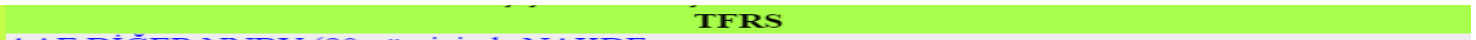 } \\
\hline $\begin{array}{l}\text { AAE DİĞER NNBV (90 gün içinde NAKDE } \\
\text { ÇEVRILEBILECEK) }\end{array}$ & $12,000.00$ & \\
\hline $\begin{array}{l}\text { AEH ANA ORTAKLIĞIN KILIT YÖNETICI } \\
\text { PERSONELINDEN ALACAKLAR }\end{array}$ & $16,000.00$ & \\
\hline AEM PERSONELDEN AIACAKLAR & $2,000.00$ & \\
\hline FIN VADE FARKI FINANSMAN KAYBI & 58.50 & \\
\hline AEO ILTA ERTELENMISS FINANSMAN KAZANCI $(-)$ & & 58.50 \\
\hline 135 PERSONELDEN ALACAKLAR & & $30,000.00$ \\
\hline & $30,058.50$ & $30,058.50$ \\
\hline
\end{tabular}

2.1.11. TDHP 13* Diğer Alacaklar hesap grubundan 136 Diğer Çeşitli Alacaklar Hesab1

31.12.20XX-1 tarihi itibariyle VUK'na göre düzenlenen Bilançoda Diğer Çeşitli Alacaklar hesap grubuna yönelik veriler şöyledir (MOMTOS, 2017). 

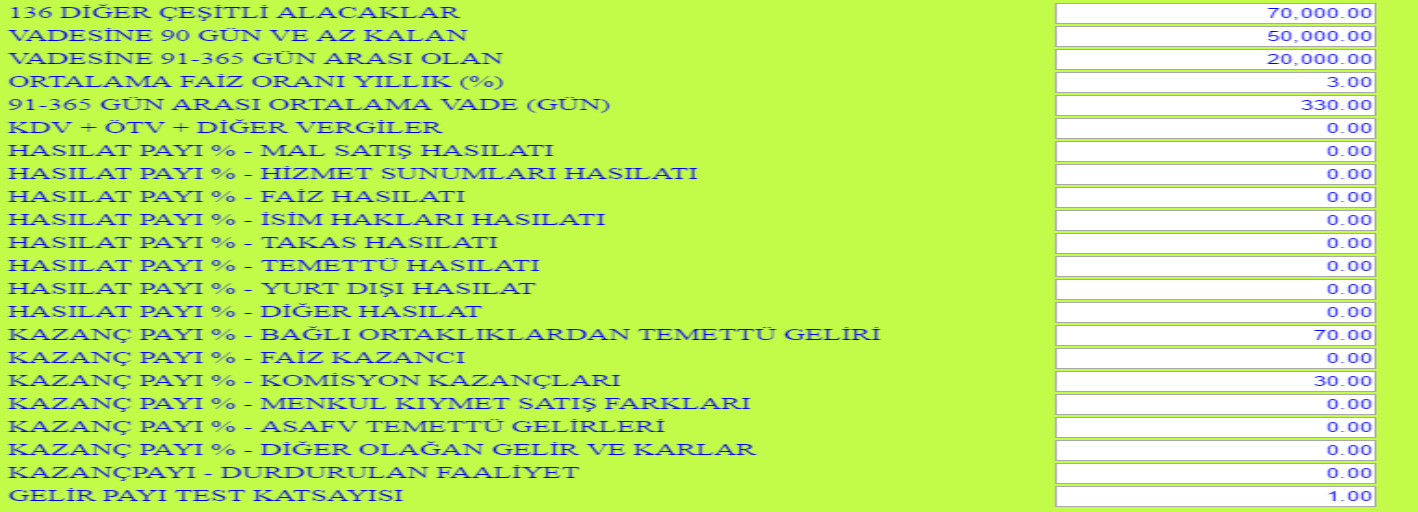

136 Diğer Çeşitli Alacaklar Hesabında Bulunan Tutarlara Yönelik Açıklamalar Şöyledir,

- [VADESINE 90 GÜN VE AZ KALAN], VADESINE 90 GÜN VE AZ KALAN,

- [VADESINE 91-365 GÜN ARASI OLAN],VADESINE 91-365 GÜN ARASI OLAN,

- [AĞIRLIKLI ORTALAMA FAİZ ORANI YILLIK], AĞIRLIKLI ORTALAMA FAIZZ ORANI YILLIK,

- [AĞIRLIKLI ORTALAMA VADE (GÜN)], AĞIRLIKLI ORTALAMA VADE (GÜN),

- [KDV+ÖTV+DİĞER VERGİLER\%], KDV+ÖTV+DİĞER VERGİLER\%,

- [KAZANÇ PAYI\% - BAĞLI ORTAKLIKLARDAN TEMETTÜ GELİRİ], KAZANÇ PAYI\% - BAĞLI ORTAKLIKLARDAN TEMETTÜ GELİRI,

- [KAZANÇ PAYI\% - KOMISYON KAZANÇLARI], KAZANÇ PAYI\% KOMISYON KAZANÇLARI,

- [GELİR PAYI TEST KATSAYISI], GELİR PAYI TEST KATSAYISI olarak dikkate alınir.

\begin{tabular}{|c|c|}
\hline 136 DİG̈ER ÇEŞITLLI ALACAKLAR & $70,000.00$ \\
\hline AAE DİGER NNBV ( 90 gün içinde NAKDE ÇEVRİLEBILECEK) & $50,000.00$ \\
\hline AFE DIG̈ER ÇEŞITLI ALACAKLAR & $20,000.00$ \\
\hline FH19 KOMISYON KAZANÇLARI & -115.49 \\
\hline FHB BAĞLI ORTAKLIKLARDAN TEMETTÜ GELIRLERİ & -269.48 \\
\hline AFF DIAL ERTELENMISS FINANSMAN KAZANCI $(-)$ & 384.97 \\
\hline
\end{tabular}

Şekil 6. Yeni TTK Çerçevesinde 136 BAĞLI DİĞER ÇEŞİTLİ ALACAKLAR hesabının TFRS 1 'e Göre Açılış Finansal Tablolarına Aktarılması

- [VADESINE 90 GÜN VE AZ KALAN] olarak gösterilen 50.000TL tutar AAE DİĞER NNBV(90 GÜN İÇİNDE NAKDE ÇEVRILEBILECEK) hesabına,

- [VADESİNE 91-365 GÜN ARASI OLAN],]+[KDV+ÖTV+DİĞER VERGILLER] hesabiyla, $20.000 \mathrm{TL}+$ 0TL $=20.000 \mathrm{TL}$ olarak AFE DİĞER ÇEŞİTLİ ALACAKLAR hesabina,

- [((VADESINNE 91-365 GÜN ARASI OLAN)/(1+(AĞIRLIKLI ORTALAMA FAİZ ORANI YILLIK/100) $)^{\wedge}(($ 91-365 GÜN ARASI AĞIRLIKLI ORTALAMA VADE 90)/365))- VADESİNE 91-365 GÜN ARASI OLAN)*(KAZANÇ PAYI (YÜZDE) KOMISYON KAZANÇLARI/100)]hesabiyla, $\left[((20.000) /(1+3 / 100))^{\wedge}((330-\right.$ 90)/365))-20.000)*(30/100)] = -115,49 olarak FH19 KOMISYON KAZANÇLARI hesabina, 
- $\quad$ [((VADESINE 91-365 GÜN ARASI OLAN)/(1+(AĞIRLIKLI ORTALAMA FAİZ ORANI YILLIK/100) $)^{\wedge}(($ 91-365 GÜN ARASI AĞIRLIKLI ORTALAMA VADE 90)/365))- VADESİNE 91-365 GÜN ARASI OLAN)*(KAZANÇ PAYI (YÜZDE) BAĞLI ORTAKLIKLARDAN TEMETTÜ GELİRLERİ/100)] hesabiyla, $\left.\left.\left[((20.000) /(1+3 / 100))^{\wedge}((330-90) / 365)\right)-20.000\right)^{*}(70 / 100)\right]=-269,48$ olarak FHB BAĞLI ORTAKLIKLARDAN TEMETTÜ GELİRLERİ hesabına,

- $\quad$ [((VADESINE 91-365 GÜN ARASI OLAN)/(1+(AĞIRLIKLI ORTALAMA FAİZ ORANI YILLIK/100)^^(( 91-365 GÜN ARASI AĞIRLIKLI ORTALAMA VADE 90)/365))- VADESINE 91-365 GÜN ARASI OLAN $)^{*}(-1)$ hesabiyla, $\left.\left.((20.000) /(1+3 / 100))^{\wedge}((330-90) / 365)\right)-20.000\right)^{*}(-1)=384,97$ olarak AFF DİAL ERTELENMIŞFINANSMAN KAZANCI (-) hesabına aktarılmıştır.

VUK'tan TFRS'na Geçiş sürecinde bir DÜZELTME KAYDI yapılmayacaktır. Ancak anlaşılırlığı arttırmak amacıyla aşağıdaki gibi bir YEVMİYE MADDESİ çalışma kâğıtlarında SAĞLAMA aracı olarak kullanılabilir.

\begin{tabular}{lc|}
\multicolumn{1}{c|}{ TFRS } & \\
AAE DİGER NNBV (90 gün içinde NAKDE ÇEVRILEBILECEK) & $50,000.00$ \\
AFE DIG̈ER ÇEŞITLI ALACAKLAR & $20,000.00$ \\
FH19 KOMISYON KAZANÇLARI & 115.49 \\
FHB BAĞI ORTAKLIKLARDAN TEMETTÜ GELIRLERİ & 269.48 \\
AFF DIAL ERTELENMIS FINANSMAN KAZANCI (-) & 384.97 \\
136 DIGGR ÇEŞITLI ALACAKLAR & $70,384.97$ \\
\hline
\end{tabular}

\subsubsection{TDHP $13 *$ Diğer Alacaklar hesap grubundan 137 Diğer Alacak Senetleri Reeskontu (-) Hesab1}

31.12.20XX-1 tarihi itibariyle VUK'na göre düzenlenen Bilançoda 137 Diğer Alacak Senetleri Reeskontu (-) hesabına yönelik veriler şöyledir (MOMTOS, 2017).

137 DİGER ALACAK SENETLERI REESKONTU (-) $1,000.00$

DIGER ALACAK SENETLERI REESKONTU (-) $1,000.00$

137 Diğer Alacak Senetleri Reeskontu (-)Hesabında Bulunan Tutarlara Yönelik Açıklamalar Şöyledir,

[DİĞER ALACAK SENETLERİ REESKONTU (-)],DİĞER ALACAK SENETLERİ REESKONTU (-), olarak dikkate alınır.

\begin{tabular}{|l|r|}
\hline 137 DIGGER ALACAK SENETLERİ REESKONTU (-) & $\mathbf{1 , 0 0 0 . 0 0}$ \\
\hline FLC SF ÖNCEKİ DÖNEMLE İLGİLİ DÜZELTMELER (+/-) & $1,000.00$ \\
\hline
\end{tabular}

Şekil 7. Yeni TTK Çerçevesinde 137 DİĞER ALACAK SENETLERİ REESKONTU(-) hesabının TFRS 1 'e Göre Açılış Finansal Tablolarına Aktarılması

- [DİĞER ALACAK SENETLERİ REESKONTU (-)] olarak gösterilen 1.000TL tutar FLC SF ÖNCEKI DÖNEMLE İLGILİ DÜZELTMELER(+/-) hesabına,

VUK'tan TFRS'na Geçiş sürecinde bir DÜZELTME KAYDI yapılmayacaktır. Ancak anlaşılırlığı arttırmak amacıyla aşağıdaki gibi bir YEVMİYE MADDESİ çalışma kâğıtlarında SAĞLAMA aracı olarak kullanılabilir.

\begin{tabular}{|c|c|c|}
\hline \multicolumn{3}{|l|}{ TFRS } \\
\hline 137 DİGER ALACAK SENETLERİ REESKONTU (-) & $1,000.00$ & \\
\hline $\begin{array}{l}\text { FLC SF ÖNCEKİ DÖNEMLE İLGILİ DÜZELTMELER } \\
(+/-)\end{array}$ & & $1,000.00$ \\
\hline & $1,000.00$ & $1,000.00$ \\
\hline
\end{tabular}




\subsubsection{TDHP 13* Diğer Alacaklar hesap grubundan 138 Şüpheli Diğer Alacaklar Hesab1}

31.12.20XX-1 tarihi itibariyle VUK'na göre düzenlenen Bilançoda 138 Şüpheli Diğer Alacaklar hesabına yönelik veriler şöyledir (MOMTOS, 2017).

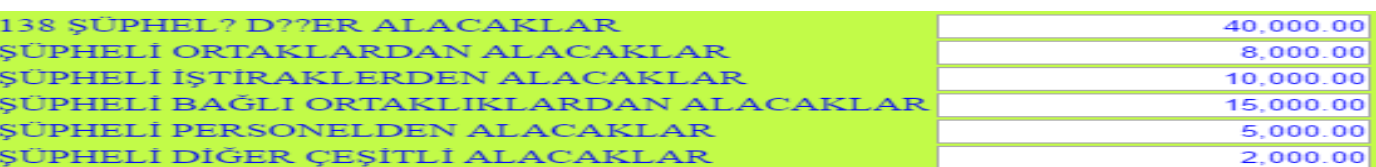

138 Şüpheli Diğer Alacaklar Hesabında Bulunan Tutarlara Yönelik Açıklamalar Şöyledir,

- [ŞÜPHELİ ORTAKLARDAN ALACAKLAR], ŞÜPHELİ ORTAKLARDAN ALACAKLAR,

- [ŞÜPHELİ İ̧TIRARLERDEN ALACAKLAR], ŞÜPHELİ İ̧TIIRAKLERDEN ALACAKLAR,

- [ŞÜPHELİ BAĞLI ORTAKLIKLARDAN ALACAKLAR], ŞÜPHELİ BAĞLI ORTAKLIKLARDAN ALACAKLAR,

- [ŞÜPHELİ PERSONELDEN ALACAKLAR], ŞÜPHELİ PERSONELDEN ALACAKLAR,

- [ŞÜPHELİ DİĞER ÇEŞITLİ ALACAKLAR], ŞÜPHELİ DİĞER ÇEŞITLİ ALACAKLAR, olarak dikkate alınır.

\begin{tabular}{l|r}
\hline 138 ŞÜPHELI DIGGER ALACAKLAR & $\mathbf{4 0 , 0 0 0 . 0 0}$ \\
\hline AED BAĞLI ORTAKLIKLARDAN ALACAKLAR & $15,000.00$ \\
\hline AEE İSTIRAKLERDEN ALACAKLAR & $10,000.00$ \\
\hline AEJ ORTAKLARDAN ALACAKLAR & $8,000.00$ \\
\hline AEM PERSONELDEN ALACAKLAR & $5,000.00$ \\
\hline AFE DÍĞER CESİTLİ ALACAKLAR & $2,000.00$
\end{tabular}

Şekil 8. Yeni TTK Çerçevesinde 138 ŞÜPHELİ DİĞER ALACAKLAR hesabının TFRS 1

'e Göre Açılış Finansal Tablolarına Aktarılması

- [ŞÜPHELİ BAĞLI ORTAKLIKLARDAN ALACAKLAR] olarak gösterilen 15.000TL tutar AED BAĞLI ORTAKLIKLARDAN ALACAKLAR hesabına,

- [ŞÜPHELİ İSTTIRAKLERDEN ALACAKLAR] olarak gösterilen 10.000TL tutar AEE ISSTİRAKLERDEN ALACAKLAR hesabına,

- [ŞÜPHELİ ORTAKLARDAN ALACAKLAR] olarak gösterilen 8.000TL tutar AEJ ORTAKLARDAN ALACAKLAR hesabina,

- [ŞÜPHELI PERSONELDEN ALACAKLAR] olarak gösterilen 5.000TL tutar AEM PERSONELDEN ALACAKLAR hesabina,

- [ŞÜPHELİ DİĞER ÇEŞiTLİ ALACAKLAR] olarak gösterilen 2.000TL tutar AFE DİĞER ÇEŞITTLİ ALACAKLAR hesabına,

VUK'tan TFRS'na Geçiş sürecinde bir DÜZELTME KAYDI yapılmayacaktır. Ancak anlaşılırlığı arttırmak amacıyla aşağıdaki gibi bir YEVMIYYE MADDESİ çalışma kâğıtlarında SAĞLAMA aracı olarak kullanılabilir.

\begin{tabular}{|c|c|c|}
\hline \multicolumn{3}{|l|}{ 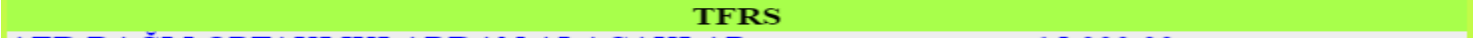 } \\
\hline AED BAGLI ORTAKLIKLARDAN ALACAKLAR & $15,000.00$ & \\
\hline AEE İSTTIRAKLERDEN ALACAKLAR & $10,000.00$ & \\
\hline AEJ ORTAKLARDAN ALACAKLAR & $8,000.00$ & \\
\hline AEM PERSONELDEN ALACAKLAR & $5,000.00$ & \\
\hline AFE DİĞER ÇEŞİTLİ ALACAKLAR & $2,000.00$ & \\
\hline 138 ŞÜPHELİ DİĞER ALACAKLAR & & $40,000.00$ \\
\hline & $40,000.00$ & $40,000.00$ \\
\hline
\end{tabular}




\subsubsection{TDHP 13* Diğer Alacaklar hesap grubundan 139 Şüpheli Diğer Alacaklar Karşılığ1 (-) Hesabı}

31.12.20XX-1 tarihi itibariyle VUK'na göre düzenlenen Bilançoda 139 Şüpheli Diğer Alacaklar Karşılığı (-) hesabına yönelik veriler şöyledir (MOMTOS, 2017).

\begin{tabular}{l|r|}
139 SUPHEII DIGER CESTITLI ALACAKIAR KARIISILIĞO $(-)$ & $8,000.00$ \\
KANUNEN KABUL EDILMEYEN GIDER $(\rightarrow)$ & $5,000.00$ \\
KANUNEN KABUL EDILEN GIDER $(\rightarrow)$ & $3,000.00$
\end{tabular}

139 Şüpheli Diğer Alacaklar Karşılığı (-) Hesabında Bulunan Tutarlara Yönelik Açıklamalar Şöyledir,

- [KANUNEN KABUL EDİLMEYEN GIDER], KANUNEN KABUL EDİLMEYEN GIDER,

- [KANUNEN KABUL EDİLEN GIDER], KANUNEN KABUL EDİLEN GİDER, olarak dikkate alınır.

\begin{tabular}{|l|r|}
\hline 139 ŞÜPHELİ DIGER ALACAKLAR KARŞILIĞI (-) & $\mathbf{8 , 0 0 0 . 0 0}$ \\
\hline AFG DİAL ŞÜPHELI ALACAK KARŞILIĞI (-) & 8,000.00 \\
Şekil 9. Yeni TTK Çerçevesinde 139 ŞÜPHELİ DİĞER ALACAKLAR KARŞILIĞI(-)
\end{tabular}
hesabının TFRS 1 'e Göre Açılış Finansal Tablolarına Aktarılması

- [ŞÜPHELİ DİĞER ALACAKLAR KARŞILIĞI (-)] olarak gösterilen 8.000TL tutar AFG DİAL ŞÜPHELI ALACAK KARŞILIĞI (-) hesabına,

VUK'tan TFRS'na Geçiş sürecinde bir DÜZELTME KAYDI yapılmayacaktır. Ancak anlaşılırlığı arttırmak amacıyla aşağıdaki gibi bir YEVMIYE MADDESİ çalışma kâğıtlarında SAĞLAMA aracı olarak kullanılabilir.

\begin{tabular}{|c|c|c|}
\hline \multirow{3}{*}{$\begin{array}{l}\text { TFRS } \\
139 \text { ŞÜPHELI DİĞER ALACAKLAR KARŞILIĞI (-) } \\
\text { AFG DİAL ŞÜPHELI ALACAK KARȘILIG̈I (-) }\end{array}$} & \multirow{2}{*}{\multicolumn{2}{|c|}{$8,000.00$}} \\
\hline & & \\
\hline & 800000 & $8,000.00$ \\
\hline
\end{tabular}

\subsection{TDHP Diğer Alacaklar Hesap Grubuna Ait 31 Aralık 20XX-1 Tarihli Bilgiler}

TDHP 13* Diğer Alacaklar hesap grubuna ait 31 Aralık 20XX-1 tarihli bilgiler aşağıdaki gibidir.

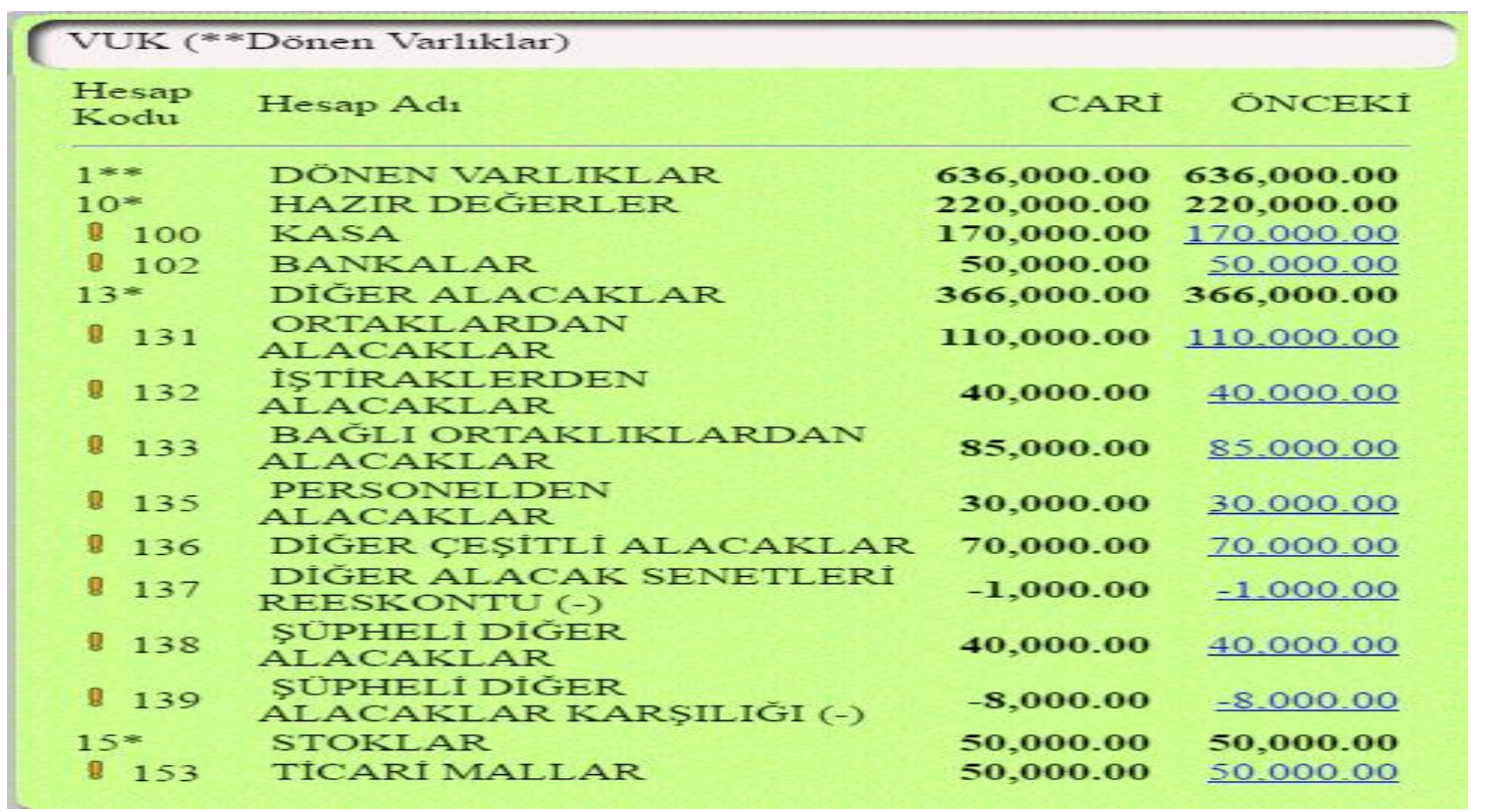


2.3. TDHP Diğer Alacaklar hesap grubunun TFRS'lerin ilk kez uygulandığı 01 Ocak 20XX tarihli Açılış Finansal Tablolarına aktarılmış hali(Vergi Etkisi Öncesi)

Vergi Usul Kanunu 'na göre hazırlanmış Bilançoda;

- 131 ORTAKLARDAN ALACAKLAR Hesabında yer alan tutar, TFRS Açılış Finansal Durum Tablosunda, AAE DİĞER NNBV (90 gün içinde NAKDE ÇEVRILEBİLECEK), AEJ ORTAKLARDAN ALACAKLAR, FIN VADE FARKI FINANSMAN KAYBI, AEO İLTA ERTELENMIŞ FINANSMAN KAZANCI(-) hesaplarına,

- 132 İşTİRAKLERDEN ALACAKLAR Hesabinda yer alan tutar, TFRS Açılış Finansal Durum Tablosunda, AAE DİĞER NNBV (90 gün içinde NAKDE ÇEVRILEBİLECEK), AEE İSTTİRAKLERDEN ALACAKLAR, FIN VADE FARKI FINANSMAN KAYBI, AEO İLTA ERTELENMIŞ FINANSMAN KAZANCI(-) hesaplarına,

- 133 BAĞLI ORTAKLIKLARDAN ALACAKLAR Hesabında yer alan tutar, TFRS Açllış Finansal Durum Tablosunda, AAE DİĞER NNBV (90 gün içinde NAKDE ÇEVRILEBİLECEK), AED BAĞLI ORTAKLIKLARDAN ALACAKLAR, FIN VADE FARKI FINANSMAN KAYBI, AEO İLTA ERTELENMIŞ FINANSMAN KAZANCI(-) hesaplarına,

- 135 PERSONELDEN ALACAKLAR Hesabında yer alan tutar, TFRS Açllış Finansal Durum Tablosunda, AAE DİĞER NNBV (90 gün içinde NAKDE ÇEVRİLEBILECEK), AEH ANA ORTAKLIĞIN KİİT YÖNETICİ PERSONELINDEN ALACAKLAR, AEM PERSONELDEN ALACAKLAR, FIN VADE FARKI FINANSMAN KAYBI, AEO İLTA ERTELENMIŞ FINANSMAN KAZANCI(-) hesaplarına,

- 136 DİĞER ÇEŞİTLİ ALACAKLAR Hesabında yer alan tutar, TFRS Açılış Finansal Durum Tablosunda, AAE DİĞER NNBV (90 gün içinde NAKDE ÇEVRİLEBİLECEK), AFE DİĞER ÇEŞITTLİ ALACAKLAR, FH19 KOMİSYON KAZANÇLARI, FHB BAĞLI ORTAKLIKLARDAN TEMETTÜ GELİRLERI, AFF DİAL ERTELENMIŞ FİNANSMAN KAZANCI(-) hesaplarına,

- 137 DİĞER ALACAK SENETLERİ REESKONTU (-) Hesabında yer alan tutar, TFRS Açlış Finansal Durum Tablosunda, FLC SF ÖNCEKİ DÖNEMLE İLGİLI DÜZELTMELER (-/+) hesabina,

- 138 ŞÜPHELİ DİĞER ALACAKLAR Hesabinda yer alan tutar, TFRS Açılış Finansal Durum Tablosunda, AED BAĞLI ORTAKLIKLARDAN ALACAKLAR, AEE ISSTTIRAKLERDEN ALACAKLAR, AEJ ORTAKLARDAN ALACAKLAR, AEM PERSONELDEN ALACAKLAR, AFE DİĞER ÇEŞITTLİ ALACAKLAR, hesaplarına,

- 139 ŞÜPHELİ DİĞER ALACAKLAR KARŞILIĞI (-) Hesabında yer alan tutar, TFRS Açliş̧ Finansal Durum Tablosunda, AFG DİAL ŞÜPHELİ ALACAK KARŞILIĞI (-) hesabına, 
Özetle VUK ‘a göre hazırlanan bir bilançoda bulunan DİĞER ALACAKLAR Hesap Grubu, TFRS yapısı gereği sadece TFRS Açılış Finansal Durum Tablosuna değil,

Şekil 10`da görüldüğü üzere Özkaynaklar Değişim Tablosu;

Şekil 11'de görüldüğü üzere Nakit Akış Tablosunun tüm bölümlerine;

Şekil 12‘de görüldüğü üzere Finansal Durum Tablosunun birden fazla hesap grubuna bilgi aktarmaktadır.

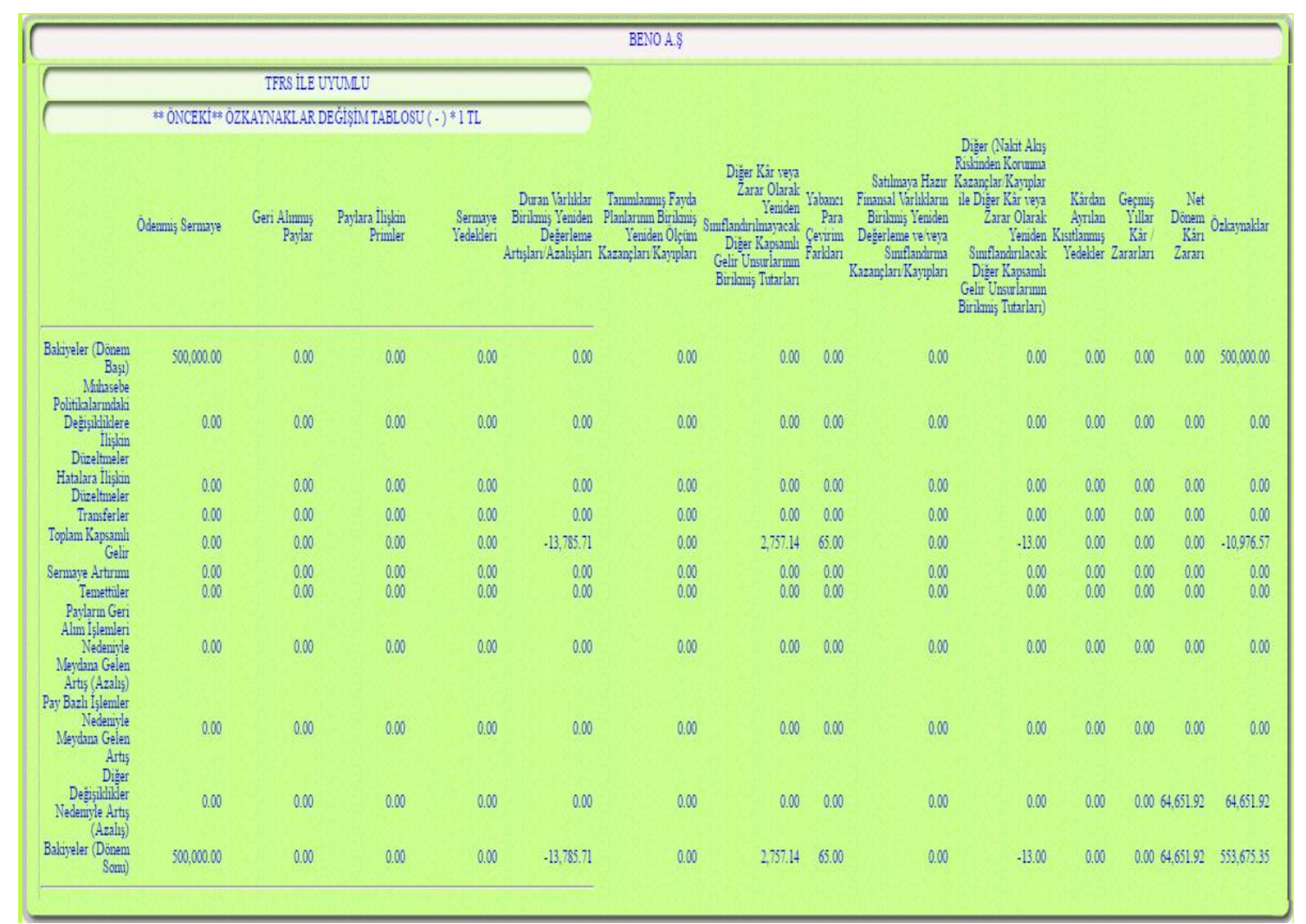

Şekil 10. VUK esaslarına göre 13 DİĞER ALACAKLAR Hesap Grubunun TFRS1' e Göre Açlış Finansal Tablolarına Aktarılması Sonucunda oluşan ÖZKAYNAKLAR DEĞİşiM TABLOSU (MOMTOS, 2017).

VUK esaslarına göre 13 DİĞER ALACAKLAR Hesap Grubunun TFRS1' e Göre Açılış Finansal Tablolarına Aktarılması Sonucunda “ÖNCEKİ” ÖZKAYNAKLAR DEĞIŞIIM TABLOSU oluşturulmuştur. www.MUMEYEK.org adresinde bulunan MOMTOS (Mumeyek Online Mali Tablo Oluşturma Sistemi) yazılımı aracılığı ile yapılan çeviri sonucunda oluşan SOLO “ÖNCEKİ" ÖZKAYNAKLAR DEĞIŞSIM TABLOSU görüntüsüdür. “Önceki” Özkaynaklar Değişim Tablosunda Özkaynakların Dönem Sonu bakiyesi; Ödenmiş sermaye, Duran Varlıklar Birikmiş Yeniden Değerleme Artışları/Azalışları, Diğer Kar veya Zarar Olarak Yeniden Sınıflandırılmayacak Diğer Kapsamlı Gelir Unsurlarının Birikmiş Tutarları, Yabancı Para Çevrim Farkları, Diğer Kar veya Zarar Olarak Yeniden Sınıflandırılacak Diğer Kapsamlı Gelir Unsurlarının Birikmiş Tutarları ve Net Dönem Karı toplamları 553,675.35 TL olarak yansımıştır. 


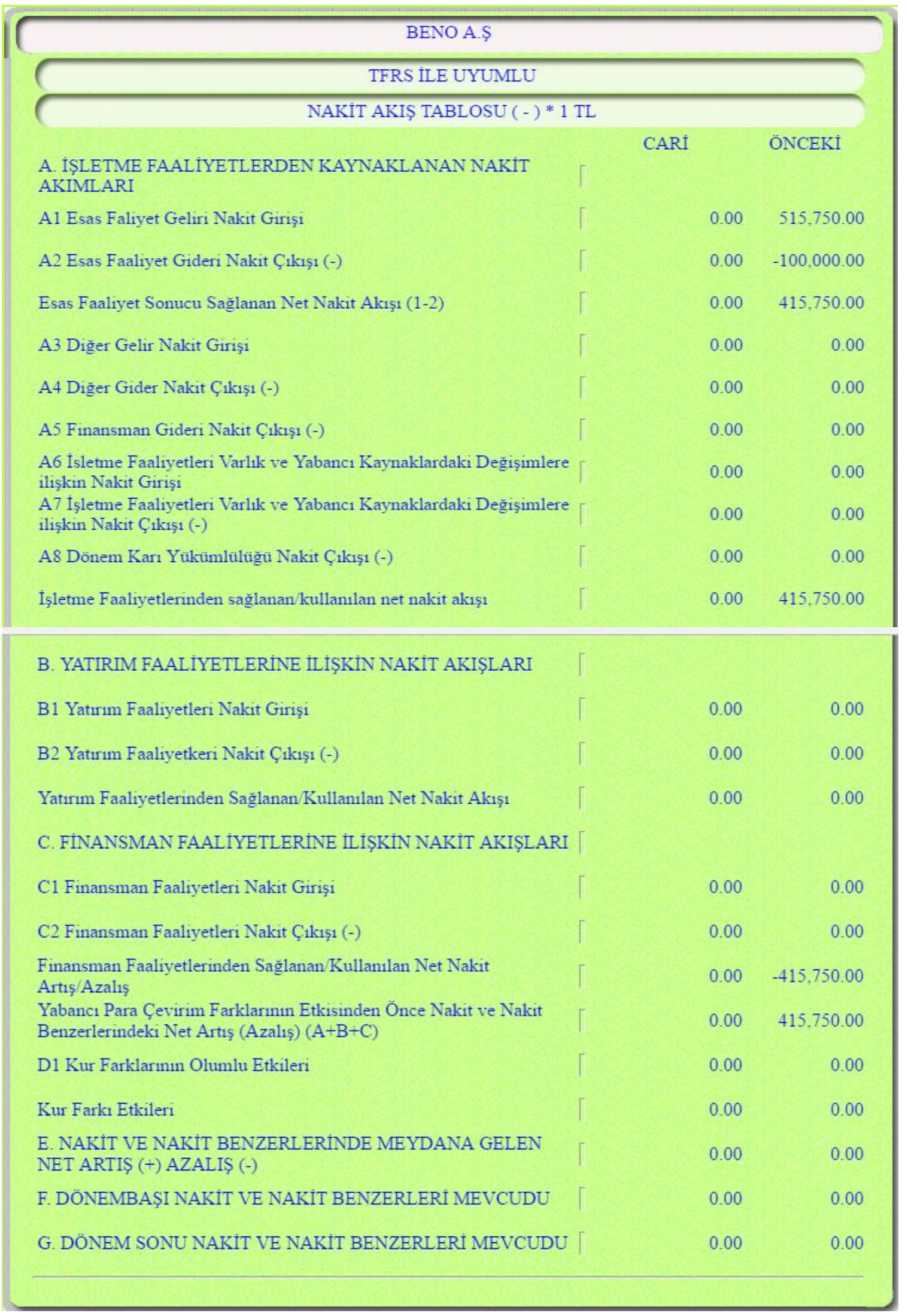

Şekil 11. VUK esaslarına göre DİĞER ALACAKLAR Hesap Grubunun TFRS1' e Göre Açılış Finansal Tablolarına Aktarılması Sonucunda oluşan NAKİT AKIŞ TABLOSU (MOMTOS, 2017). 


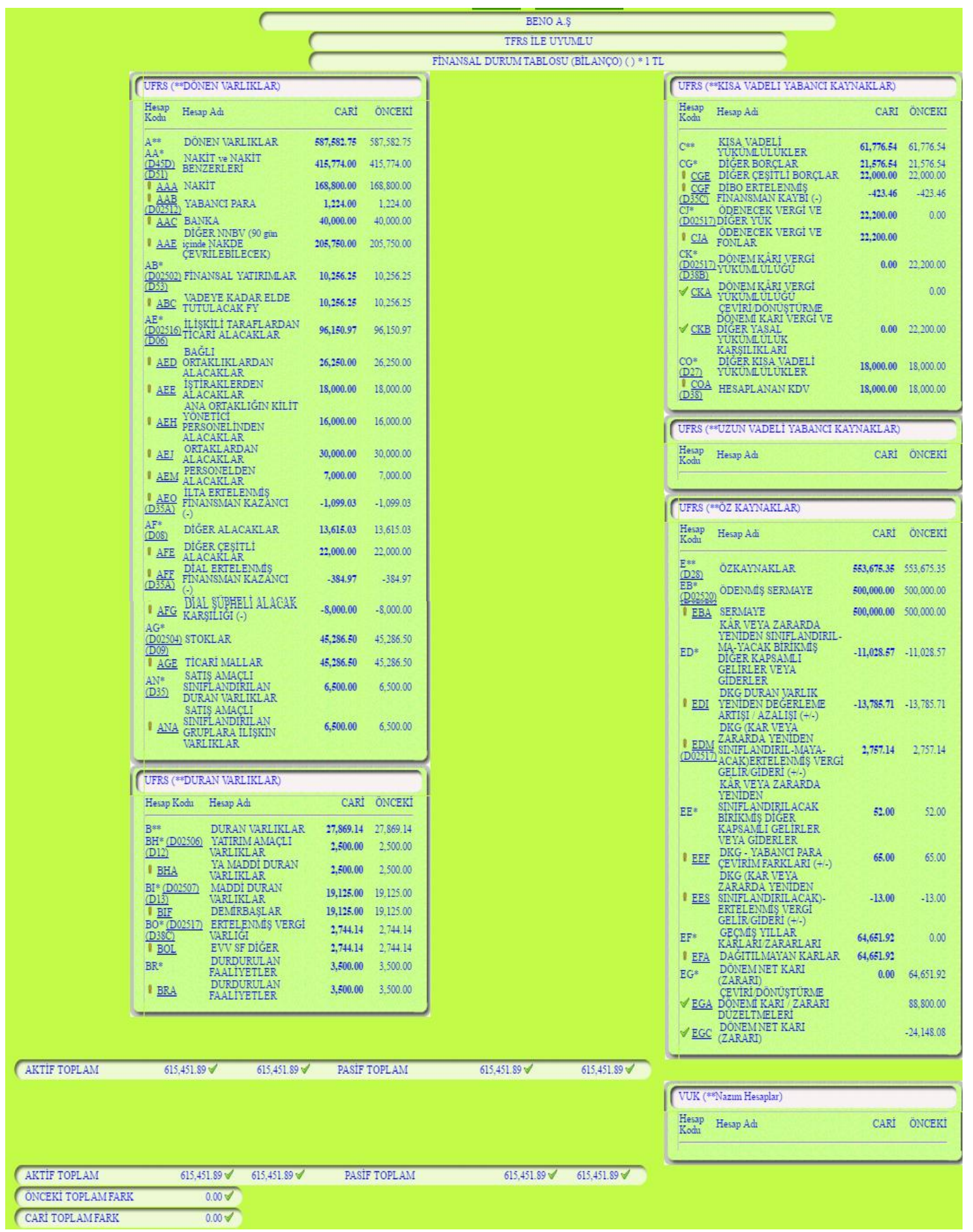

Şekil 12. VUK esaslarına göre 13 DİĞER ALACAKLAR Hesap Grubunun TFRS1' e Göre Açılış Finansal Tablolarına Aktarılması Sonucunda oluşan FINANSAL DURUM TABLOSU (MOMTOS, 2017).

Şekil 12'de Yeni TTK çerçevesinde DİĞER ALACAKLAR Hesap Grubunun TFRS 1' e göre açılış finansal durum tablolarına aktarılması sonucunda oluşan finansal durum tablosu aktif ve pasif toplamları arasındaki farkın $(615,451.89-615,451.89=0)$ olduğu görülmektedir. Bu beklenen bir sonuç olur, VUK Bilançosu hesap grupların TFRS Finansal Sonuç Tablosuna çevrilmesi gereğidir. 


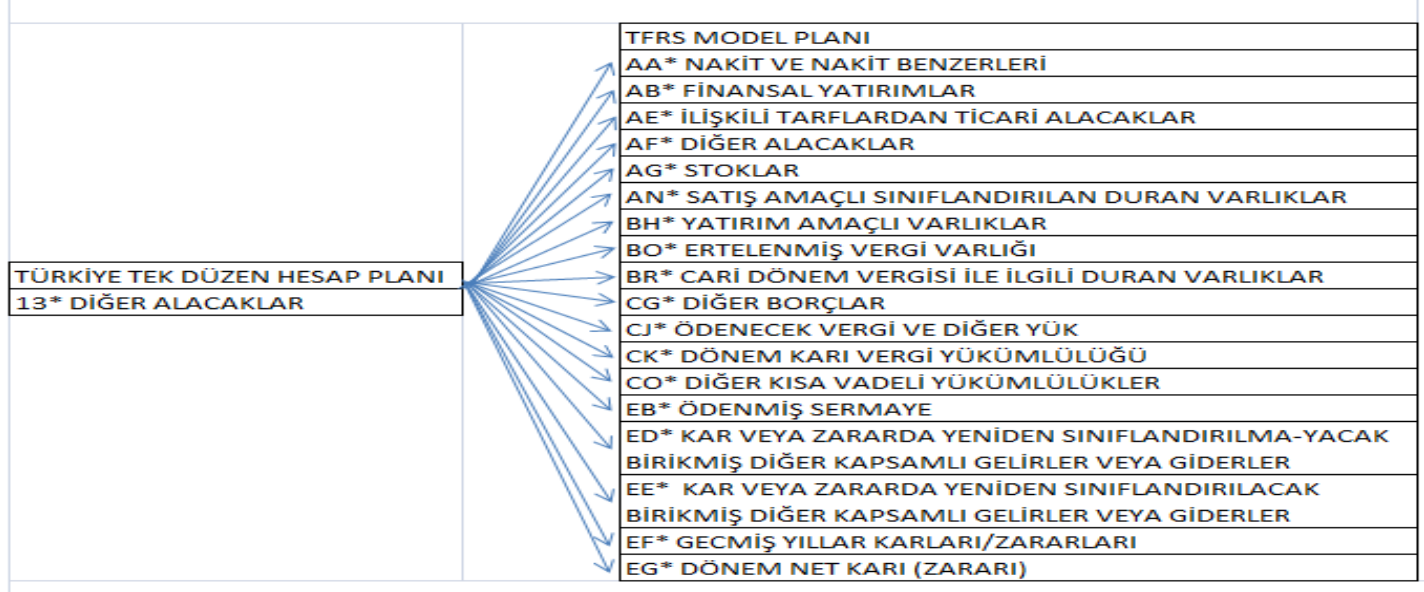

Şekil 13. VUK esaslarına göre 13 DİĞER ALACAKLAR Hesap Grubunun TFRS1' e Göre Açılış Finansal Tablolarına Aktarılması

Şekil 13 ve şekil 12 incelendiğinde VUK 'na göre hazırlanmış olan bilançoda Diğer Alacaklar Hesap Grubunda yer alan tutarlar, TFRS açılış finansal durum tablosunda, Nakit ve Nakit Benzerleri, Finansal Yatırımlar, İlişkili Taraflardan Ticari Alacaklar, Diğer Alacaklar, Stoklar, Satış Amaçlı Sınıflandırılan Duran Varlıklar, Yatırım Amaçlı Varlıklar, Ertelenmiş Vergi Varlığı, Cari Dönem Vergisi ile İlgili Duran Varlıklar, Diğer Borçlar, Ödenecek Vergi ve Diğer Yükümlülükler, Dönem Karı Vergi Yükümlülügü̈, Diğer Kısa Vadeli Yükümlülükler, Ödenmiş Sermaye, Kar ve Zararda Yeniden Sınıflandırılmayacak Birikmiş Diğer Kapsamlı Gelirler veya Giderler, Kar ve Zararda Yeniden Sınıflandırılacak Birikmiş Diğer Kapsamlı Gelirler veya Giderler, Geçmiş Yıllar Karları/Zararları, Dönem Net Karı (Zararı) hesap gruplarına aktarılmaktadır.

2.4. TDHP Diğer Alacaklar hesap grubuna ve ilişkili hesaplara ait 31Aralık 20XX1 tarihli bilgiler ve TFRS Açılış Finansal Tablolarına aktarımı (MOMTOS, 2017)

\begin{tabular}{|c|c|c|c|}
\hline \multicolumn{4}{|c|}{ BENO A.S } \\
\hline \multirow[b]{2}{*}{$\begin{array}{l}\text { Hesap } \\
\text { Kodu }\end{array}$} & \multicolumn{3}{|l|}{ GELIR TABLOSU $(-) * 1$ TL } \\
\hline & Hesap Adı & CARI & ÖNCEKI \\
\hline $60^{*}$ & BÜRÜT SATISSLAR & 0.00 & 0.00 \\
\hline $61 *$ & SATIŞ INDIRIMLERI $(-)$ & 0.00 & 0.00 \\
\hline $62 *$ & SATISLARIN MALIYETI $(-)$ & 0.00 & 0.00 \\
\hline $63=$ & FA.ALIYET GIDERIERI $(-)$ & 0.00 & 0.00 \\
\hline $64 *$ & $\begin{array}{l}\text { DIĞER FAALIYETLERDEN OLAĞAN GELIR VE } \\
\text { KARIAR }\end{array}$ & 0.00 & 0.00 \\
\hline $65=$ & $\begin{array}{l}\text { DIĞER FAALIYETLERDEN OLAĞAN GIDER VE } \\
\text { ZARARIAR }(\rightarrow)\end{array}$ & 0.00 & 0.00 \\
\hline $66 *$ & FINANSMAN GIDERIERI & 0.00 & 0.00 \\
\hline $67 *$ & OLAGAN DIȘI GELIR VE KARLAR & 0.00 & 0.00 \\
\hline $68 *$ & OLAGAN DIŞI GIDER VA ZARARLAR $(\rightarrow)$ & 0.00 & 0.00 \\
\hline $69^{*}$ & DÖNEM NET KARI (ZARARI) & 0.00 & 0.00 \\
\hline 690 & DÖNEM KARI VEYA ZARARI & 0.00 & 0.00 \\
\hline 691 & $\begin{array}{l}\text { DÖNEM KARI VERGI VE DIĞER YASAL } \\
\text { YÜKÜMLÜLÜK KARSTILIKLARI }(-)\end{array}$ & 0.00 & 0.00 \\
\hline 692 & DÖNEM NET KARI VEYA ZARARI & 0.00 & 0.00 \\
\hline & TICARI KAR MATRAHI (TKM) & 0.00 & 0.00 \\
\hline & VERGIYE TABI OLMAYAN GELIRLER (VTOG) & 0.00 & 0.00 \\
\hline & $\begin{array}{l}\text { KANUNEN KABUL EDILMEYEN GIDERIER } \\
\text { (KKEG) }\end{array}$ & 0.00 & 0.00 \\
\hline & MALI KAR MATRAHI (MKM) & 0.00 & 0.00 \\
\hline
\end{tabular}




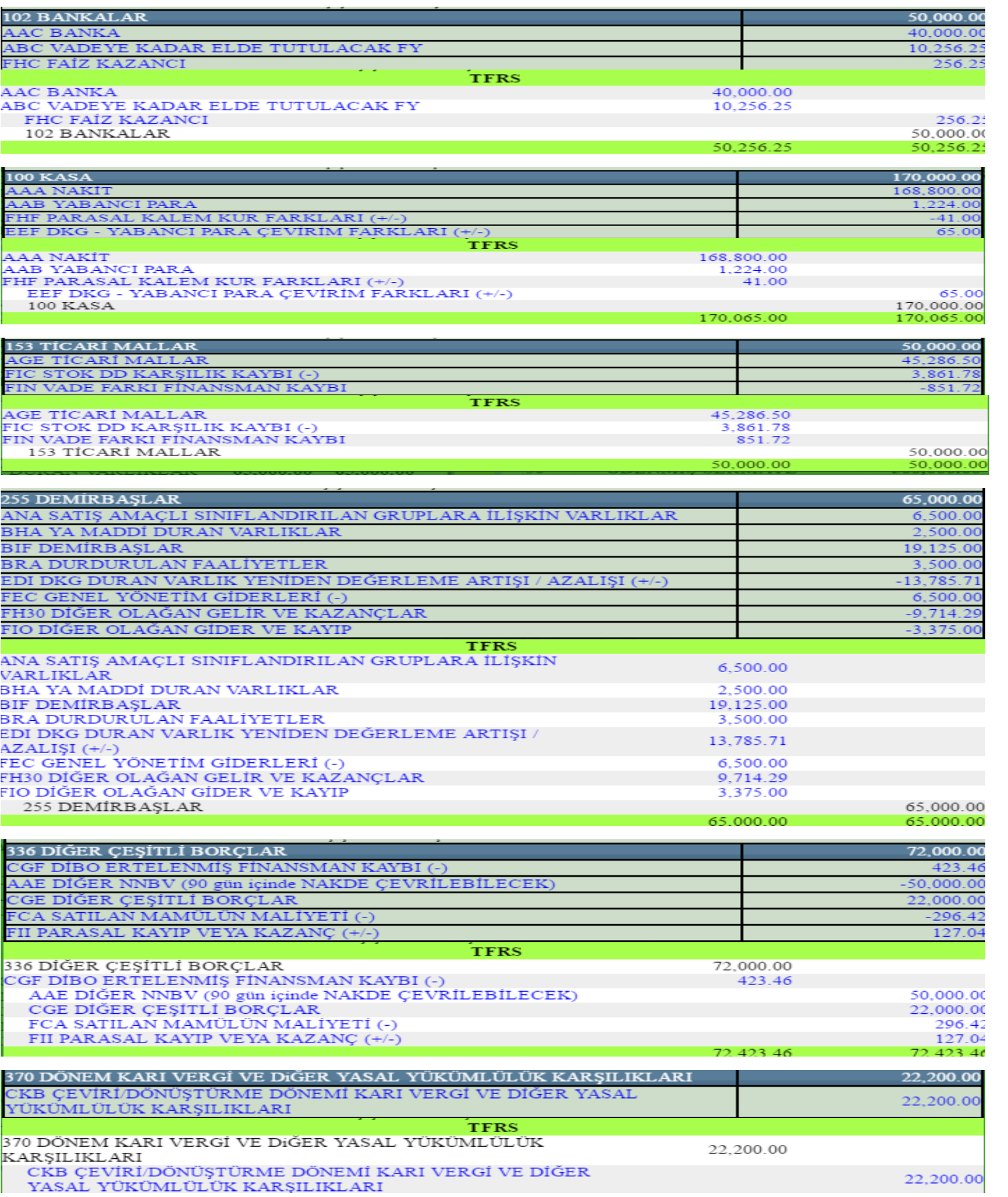

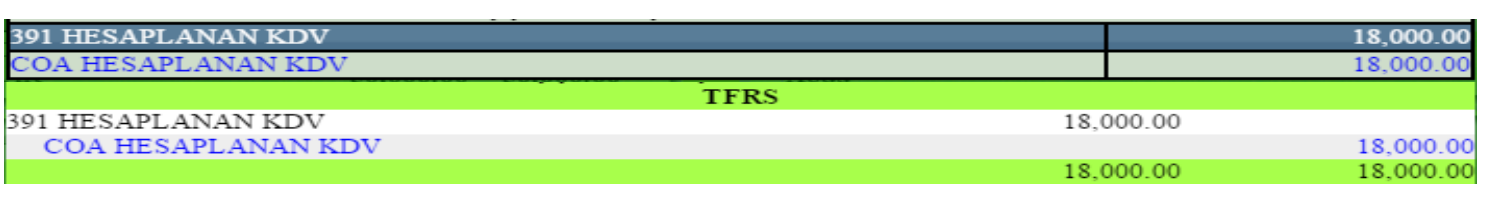

\begin{tabular}{|c|c|c|}
\hline 500 SERMAYE & & $500,000.00$ \\
\hline EBA SERMAYE & & $500,000.00$ \\
\hline \multicolumn{3}{|l|}{ TFRS } \\
\hline \multirow[b]{2}{*}{ EBA SERMAYE } & $500,000.00$ & \\
\hline & $500,000.00$ & $\begin{array}{l}500,000.00 \\
500,000.00\end{array}$ \\
\hline \multicolumn{2}{|l|}{ S90 DONEM NET KARI } & $88,800.00$ \\
\hline \multirow{2}{*}{$\begin{array}{l}\text { EGA ÇEVIRI/DÖNUSTTURME DÖNEMI KARI / ZARARI DUZELTMELERI } \\
590 \text { DÖNEM NET KARI }\end{array}$} & & 88.800 .00 \\
\hline & \multirow[t]{2}{*}{$88,800.00$} & \\
\hline $\begin{array}{l}\text { EGA CEVIRI/DONUSTURME DONEMI KARI / ZARARI } \\
\text { DUZELTMELERI }\end{array}$ & & $88,800.00$ \\
\hline
\end{tabular}




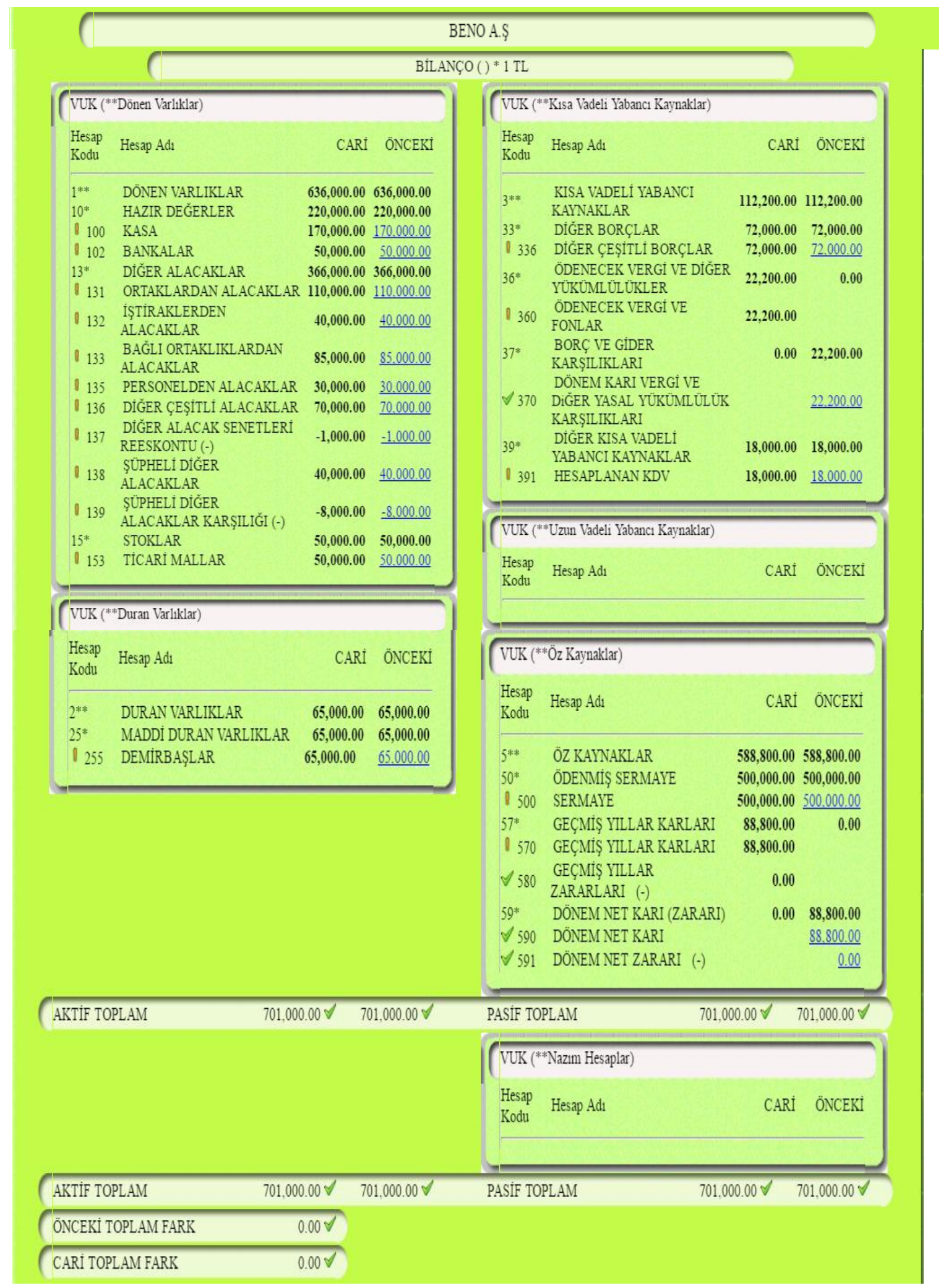

DİĞER ALACAKLAR Hesap Grubunun TFRS 1'e göre açllış finansal sonuç tablolarına aktarılması sonucunda oluşan Bilanço tablosu aktif ve pasif toplamları arasındaki farkın $(701,000.00-701,000.00=0)$ olduğu görülmektedir. Bu beklenen bir 
sonuç olur, VUK Bilançosu hesap grupların TFRS Finansal Sonuç Tablosuna çevrilmesi gereğidir.

2.5. TDHP Diğer Alacaklar hesap grubunun ve ilişkili hesapların TFRS'lerin ilk kez uygulandığı 01 Ocak 20XX tarihli Açılış Finansal Tablolarına aktarılmış hali (Vergi Etkisi Öncesi)

2.5.1. TDHP Diğer Alacaklar hesap grubunun Finansal Sonuç Tablosu (Vergi Etkisi Öncesi) (MOMTOS, 2017)

\begin{tabular}{|c|c|c|c|}
\hline \multicolumn{4}{|c|}{ BENO A.S } \\
\hline \multicolumn{4}{|c|}{ TFRS ILE UYUMIIU } \\
\hline \multirow{2}{*}{\multicolumn{4}{|c|}{$\begin{array}{l}\text { KAR VEYA ZARAR VE DIGER KAPSAMII GEIIR TABLOSU }(-)=1 \text { IL } \\
\text { EYA ZARAR IISMII }\end{array}$}} \\
\hline & & & \\
\hline$F C=(D 29)$ & SATIŞLARIN MALIYETI $(\rightarrow)$ & 296.42 & 296.42 \\
\hline 1 FCA & 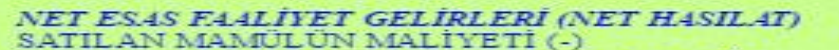 & $\begin{array}{r}0.00 \\
296.42\end{array}$ & $\begin{array}{r}0.00 \\
296.42\end{array}$ \\
\hline & $\begin{array}{l}\text { FINANS SEKTORU FALIIIYETIERINDEN BRET } \\
\text { RARZARAR }\end{array}$ & 0.00 & 0.00 \\
\hline & BURTT KAR IEYA ZARAR & 0.00 & 0.00 \\
\hline$F E=(D 312$ & FAAIIYET GIDERI ERI $(\rightarrow)$ & $-6,500.00$ & $-6,500.00$ \\
\hline FEC & GENEL YONETIM GIDERIERI $(\rightarrow)$ & $-6,500.00$ & $-6,500.00$ \\
\hline $\mathrm{FH}=\left(\mathrm{D}^{3} \mathrm{2}\right.$ & ESAS FAAI IYET KAR IEYA ZARAR & 0.00 & 0.00 \\
\hline $\mathrm{FH}=(\mathrm{D} 322$ & DIGER FA.AIYETLERDEN GELIR VE RAZANC & $-9,884.01$ & $-9,884.01$ \\
\hline & KONIISYON KAZANCI ARI & -115.49 & -115.49 \\
\hline FH & DIGER OLAGAN GELIR VE KAZANCLAR & $-9,714.29$ & $-9,714.29$ \\
\hline$=\overline{F H B}$ & BAĞII ORTAKLIKLARDAN TEMETTÜ GELIRLERI & -269.48 & -269.48 \\
\hline$\frac{F H C}{D 332}$ & FAIZ KAZANCI & 256.25 & 256.25 \\
\hline FHF & PARASAL IKALEMIKUR FARIKLARI $(+\rightarrow)$ & -41.00 & -41.00 \\
\hline$F I=(D 322$ & $\begin{array}{l}\text { DIGER FAALIYETLERDEN GIDER VE ZARAR } \\
\text { (KAYIP) }(-)\end{array}$ & $-9,060.49$ & -9.060 .49 \\
\hline 2 FIC & $\begin{array}{l}\text { OLAGAN FALAIIYET KARI IEYA ZARARI } \\
\text { STOK DD KARSTILIK KAYBI }(-)\end{array}$ & $\begin{array}{r}0.00 \\
-3,861.78\end{array}$ & $\begin{array}{r}0.00 \\
-3.561 .78\end{array}$ \\
\hline$\frac{1.10}{F I I}$ & PARASAI KAYIP VEYA KAZANC $(+\omega)$ & 127.04 & 127.04 \\
\hline FIN & VADE FARISI FINAINSMLAN KATBI & $-1,950.75$ & $-1,950.75$ \\
\hline$=\overline{\text { FIO }}$ & DIĞER OLAĞAN GIDER VE KAYYTP & $-3,375,00$ & $-3,375.00$ \\
\hline$\frac{F L}{(D O 2517 A)}$ & $\begin{array}{l}\text { SUTRDÜRULLEN FAALIYETLER NET DONEM } \\
\text { KARI(ZARARI) }\end{array}$ & $-24,148.08$ & $-24,148.08$ \\
\hline FLA & $\begin{array}{l}\text { SÜRDÜRÜLFN FAALIYETLER DONNMI } \\
\text { KARI(ZARARI) }\end{array}$ & $-25,148.08$ & $-25,148.08$ \\
\hline EFLC & SF ONCEKI DONEMIIE IL GILI DUZELTMELER $(+/-)$ & $1,000.00$ & $1,000.00$ \\
\hline $0 \overline{\text { FLI }}$ & $\begin{array}{l}\text { SURDURUIEN FA.ALIYETLER NET DONEM } \\
\text { KARTCZARART }\end{array}$ & $-24,148$. os & $-24,148.08$ \\
\hline $\mathrm{FO}=$ & TOPLAM DONEMINET DÖNEMIKÂRI(ZARART) & $-24,148$. os & $-24,148.08$ \\
\hline$\frac{\text { (DOA }}{(\mathrm{DO} 2513)}$ & TOPLAM DÖNEM NET DONNEM KÂRI(ZARARI) & $-24,148.08$ & $-24,148.08$ \\
\hline FP $=$ & DIGERR ILAPSAMILI GELIR & $-10,976.57$ & $-10,976.57$ \\
\hline FPA & & $-10,976.57$ & $-10,976.57$ \\
\hline FR= & TOPLAMI KAPSAMIII GEIIR & $-35,124.65$ & $-35,124.65$ \\
\hline & TOPLAM KAPSAMIII GELIR & & $-35,124.65$ \\
\hline
\end{tabular}




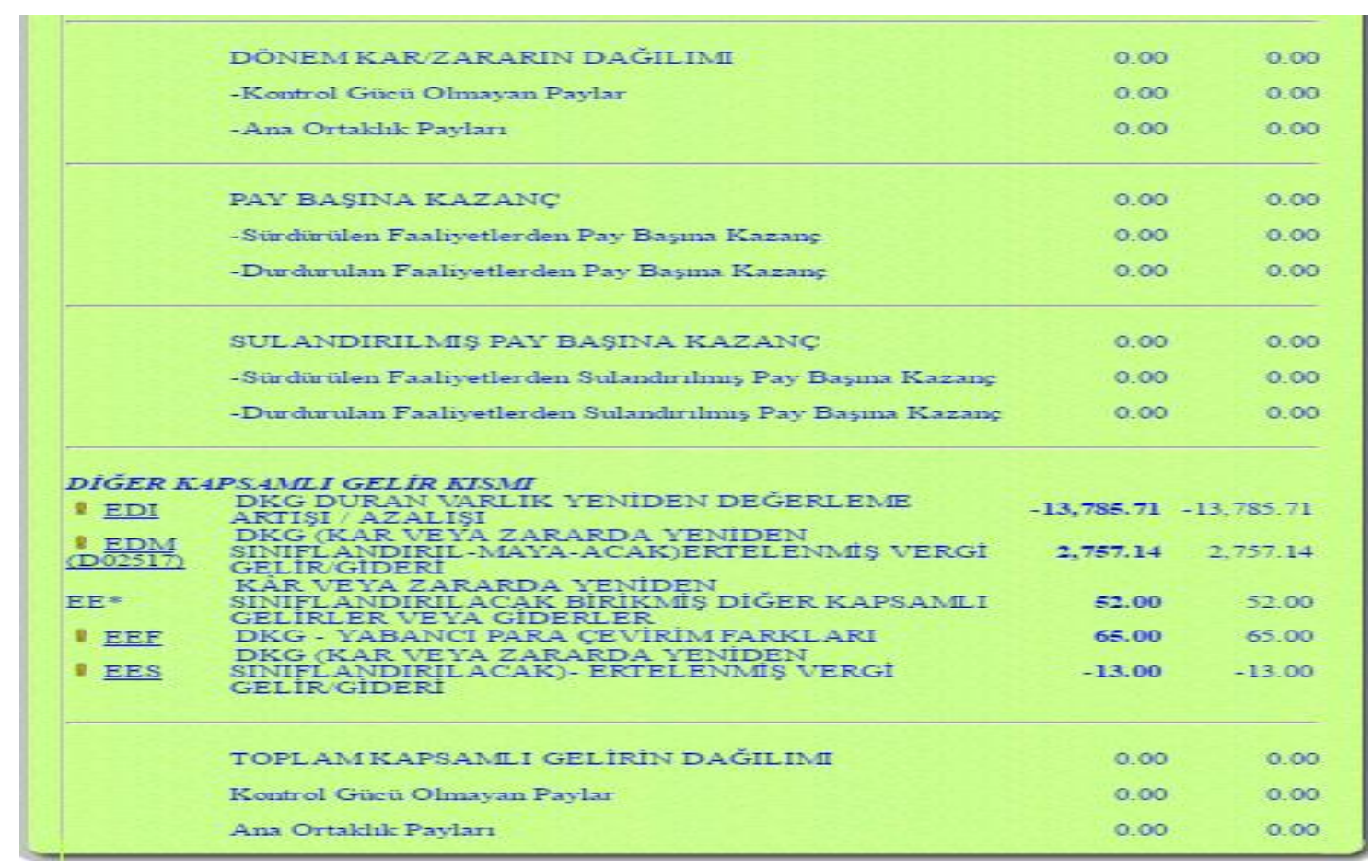

BENO A.Ş. Kar veya Zarar ve Diğer Kapsamlı Gelir Tablosunun Diğer Kapsamlı Gelir Kısmı bölümünde;

$\checkmark$ EDI - DKG Duran Varlıklar Yeniden Değerleme Artılı/Azalışı: -13,785.71 TL,

$\checkmark$ EDM (D02517) - DKG (Kar veya Zararda Yeniden Sinıflandırıl-mayacak) Ertelenmiş Vergi Gelir /Gideri: 2,754.14 TL,

$\checkmark$ EEF - DKG Yabancı Para Çevirim Farkları: 65.00 TL, EES - DKG (Kar veya Zararda Yeniden Sinıflandırılacak) Ertelenmiş Vergi Gelir /Gideri: -13.00 TL olarak www.MUMEYEK.org adresinde bulunan MOMTOS (Mumeyek Online Mali Tablo Oluşturma Sistemi) yazılımı aracılığı ile yapılan çeviri sonucunda oluşmuştur. 
2.5.2. TDHP Diğer Alacaklar hesap grubunun Özkaynaklar Değişim Tablosu (Vergi Etkisi Öncesi) (MOMTOS, 2017)

\begin{tabular}{|c|c|c|c|c|c|c|c|c|c|c|c|c|c|c|}
\hline \multicolumn{15}{|c|}{ BEVOAS } \\
\hline \multicolumn{15}{|c|}{ TRRS ILE UTCMLU } \\
\hline \multicolumn{15}{|c|}{ 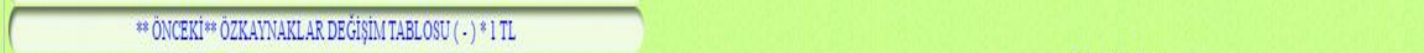 } \\
\hline & Odemis Senduge & Geri $\frac{1 \text { limms }}{\text { Payjar }}$ & $\begin{array}{l}\text { Pajyara Ilyigin } \\
\text { Primler }\end{array}$ & $\begin{array}{l}\text { Semuye } \\
\text { Yelallen }\end{array}$ & 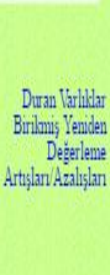 & 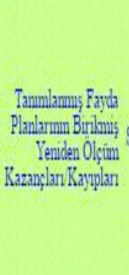 & 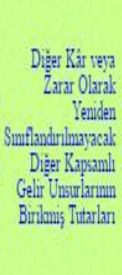 & $\begin{array}{r}\text { Yhaums } \\
\text { Pana } \\
\text { Cerrm } \\
\text { Fardann }\end{array}$ & 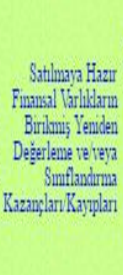 & 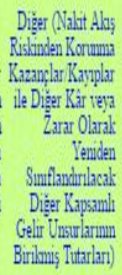 & 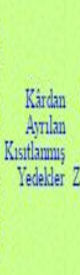 & 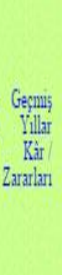 & $\begin{array}{r}\text { Net } \\
\text { Dowem } \\
\text { Kann } \\
\text { Zaran }\end{array}$ & otheyaldar \\
\hline 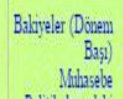 & $50,000,0$ & 0.00 & 0.00 & 0.00 & 0.00 & 0.00 & 0.00 & 0.00 & 0.00 & 0.00 & 0.00 & 0.00 & 0.00 & $500,000,0$ \\
\hline 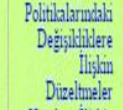 & 0.00 & 0.00 & 0.00 & 0.00 & 0.00 & 0.00 & 0.00 & 0.00 & 0.00 & 0.00 & 0.00 & 0.00 & 0.00 & 0.00 \\
\hline 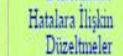 & 0.00 & 0.00 & 0.00 & 0.00 & 0.00 & 0.00 & 0.00 & 0.00 & 0.00 & 0.00 & 0.00 & 0.00 & 0.00 & 0.00 \\
\hline Transfeler & 0.00 & 0.00 & 0.00 & 0.00 & 0.00 & 0.00 & 0.00 & 0.00 & 0.00 & 0.00 & 0.00 & 0.00 & 0.00 & 0.00 \\
\hline IoplamKapxaml & 0.00 & 0.00 & 0.00 & 0.00 & $.13,78371$ & 0.00 & 27751.14 & 65.00 & 0.00 & .13 .00 & 0.00 & 0.00 & 0.00 & .00 .96 .57 \\
\hline 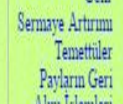 & $\begin{array}{l}0.00 \\
0.00\end{array}$ & $\begin{array}{l}0.00 \\
0.00\end{array}$ & $\begin{array}{l}0.00 \\
0.00\end{array}$ & $\begin{array}{l}0.00 \\
0.00\end{array}$ & $\begin{array}{l}0.00 \\
0.00\end{array}$ & $\begin{array}{l}0.00 \\
0.00\end{array}$ & $\begin{array}{l}0.00 \\
0.00\end{array}$ & $\begin{array}{l}0.00 \\
0.00\end{array}$ & $\begin{array}{l}0.00 \\
0.00\end{array}$ & $\begin{array}{l}0.00 \\
0.00\end{array}$ & $\begin{array}{l}0.00 \\
0.00\end{array}$ & $\begin{array}{l}0.00 \\
0.00\end{array}$ & $\begin{array}{l}0.00 \\
0.00\end{array}$ & $\begin{array}{l}0.00 \\
0.00\end{array}$ \\
\hline 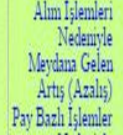 & 0.00 & 0.00 & 0.00 & 0.00 & 0.00 & 0.00 & 0.00 & 0.00 & 0.00 & 0.00 & 0.00 & 0.00 & 0.00 & 0.00 \\
\hline 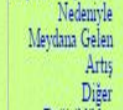 & 0.00 & 0.00 & 0.00 & 0.00 & 0.00 & 0.00 & 0.00 & 0.00 & 0.00 & 0.00 & 0.00 & 0.00 & 0.00 & 0.00 \\
\hline 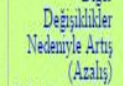 & 0.00 & 0.00 & 0.00 & 0.00 & 0.00 & 0.00 & 0.00 & 0.00 & 0.00 & 0.00 & 0.00 & & $64,651.92$ & 64.65:.2. \\
\hline $\begin{array}{r}\text { Babyeler (Dowem } \\
\text { Sounl) }\end{array}$ & $50,000,0$ & 0.00 & 0.00 & 0.00 & $.13,78577$ & 0.00 & 27751.14 & 65.00 & 0.00 & .1300 & 0.00 & & $64,651.92$ & $533,673.35$ \\
\hline
\end{tabular}




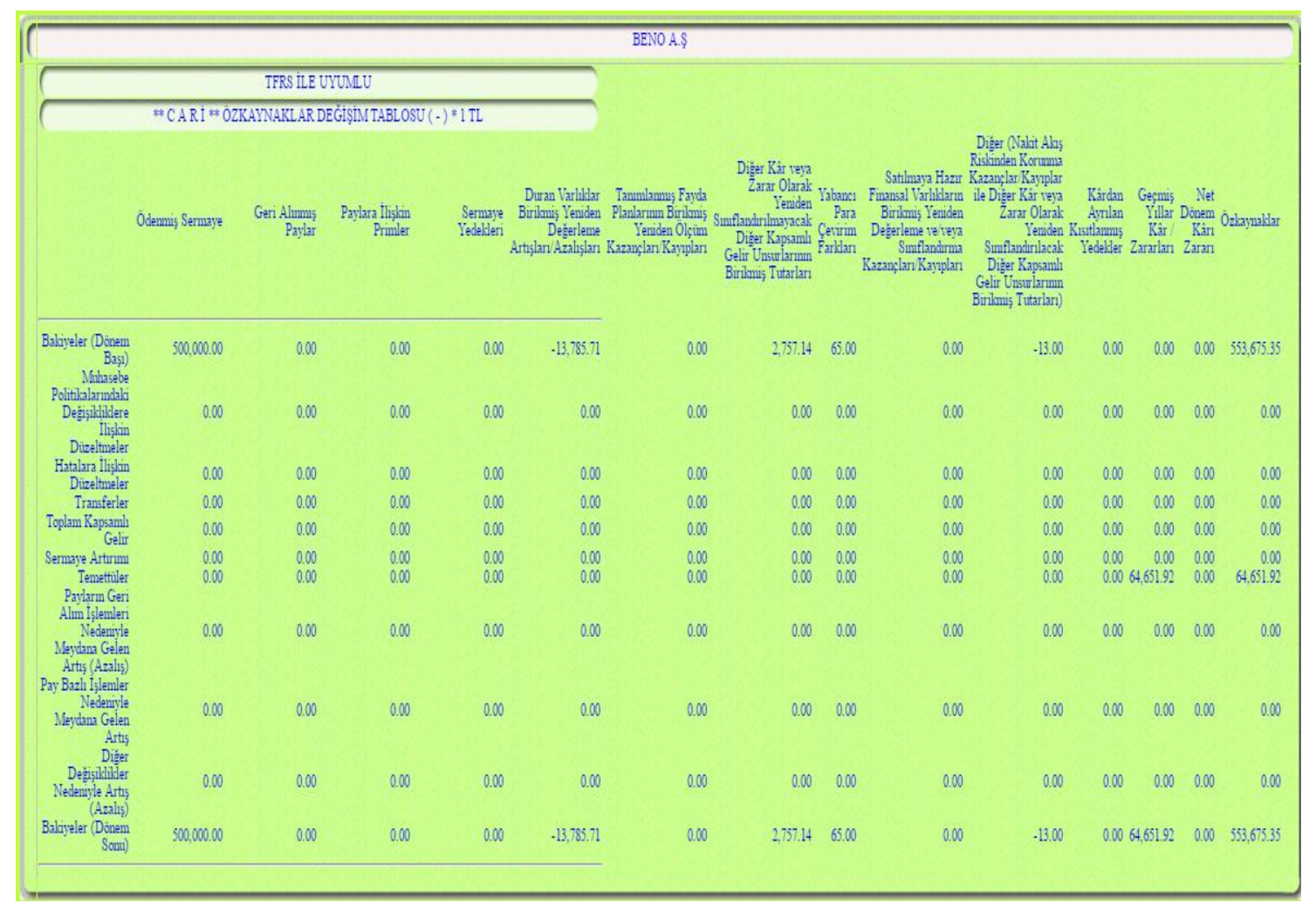

$\checkmark$ BENO A.Ş. Kar veya Zarar ve Diğer Kapsamlı Gelir Tablosunun Diğer Kapsamlı Gelir Kısmı bölümündeki EDI - DKG Duran Varlıklar Yeniden Değerleme Artış/Azalışı: -13,785.71 TL, Özkaynaklar Değişim Tablosunun Bakiyeler (Dönem Sonu) bölümü Duran Varlıklar Birikmiş Yeniden Değerleme Artışları/Azalışları hesabında gösterilmiştir.

$\checkmark$ BENO A.Ş. Kar veya Zarar ve Diğer Kapsamlı Gelir Tablosunun Diğer Kapsamlı Gelir Kısmı bölümündeki EDM (D02517) - DKG (Kar veya Zararda Yeniden Sınıflandırıl-mayacak) Ertelenmiş Vergi Gelir /Gideri: 2,754.14 TL,Özkaynaklar Değişim Tablosunun Bakiyeler (Dönem Sonu) bölümü Diğer Kar veya Zarar Olarak Yeniden Sınıflandırıl-mayacak Diğer Kapsamlı Gelir Unsurlarının Birikmiş Tutarları hesabında gösterilmiştir.

$\checkmark$ BENO A.Ş. Kar veya Zarar ve Diğer Kapsamlı Gelir Tablosunun Diğer Kapsamlı Gelir Kısmı bölümündeki EEF - DKG Yabancı Para Çevirim Farkları: 65.00 TL, Özkaynaklar Değişim Tablosunun Bakiyeler (Dönem Sonu) bölümü Yabancı Para Çevirim Farkları hesabında gösterilmiştir.

$\checkmark$ BENO A.Ş. Kar veya Zarar ve Diğer Kapsamlı Gelir Tablosunun Diğer Kapsamlı Gelir Kısmı bölümündeki EES - DKG (Kar veya Zararda Yeniden Sınıflandırılacak) Ertelenmiş Vergi Gelir /Gideri: -13.00 TL, Özkaynaklar Değişim Tablosunun Bakiyeler (Dönem Sonu) bölümü Diğer (Nakit Akış Riskinden Korunma Kazançlar/Kayıplar ile Diğer Kar veya Zarar Olarak Yeniden Sınıflandırılacak Diğer Kapsamlı Gelir Unsurlarının Birikmiş Tutarları) hesabında gösterilmiştir.

$\checkmark$ Dönem Net Kar1/ Zararı: 64,651.92 TL'dir.

$\checkmark$ Özkaynaklar: 553,675.35 TL'dir. 


\subsubsection{TDHP Diğer Alacaklar hesap grubunun Nakit Akış Tablosu (Vergi Etkisi Öncesi) (MOMTOS, 2017)}

\begin{tabular}{|c|c|c|}
\hline \multicolumn{3}{|l|}{ BENO A.S } \\
\hline \multicolumn{3}{|l|}{ TFRS ILE UYUMLU } \\
\hline NAKİT AKIŞ TABLOSU $(-) * 1 \mathrm{~T}$ & & \\
\hline $\begin{array}{l}\text { A. ISSLETME FAALIYETLERDEN KAYNAKLANAN NAKIT } \\
\text { AKIMLARI }\end{array}$ & CARİ & ÖNCEKİ \\
\hline A1 Esas Faliyet Geliri Nakit Girişi & 0.00 & $515,750.00$ \\
\hline A.2 Esas Faaliyet Gideri Nakit Çıkışı (-) & 0.00 & $-100,000.00$ \\
\hline Esas Faaliyet Sonucu Sağlanan Net Nakit Akışı (1-2) & 0.00 & $415,750.00$ \\
\hline A3 Diğer Gelir Nakit Girişi & 0.00 & 0.00 \\
\hline A4 Diğer Gider Nakit Çıkışı (-) & 0.00 & 0.00 \\
\hline A5 Finansman Gideri Nakit Çıkışı (-) & 0.00 & 0.00 \\
\hline $\begin{array}{l}\text { A6 İsletme Faaliyetleri Varlık ve Yabancı Kaynaklardaki Değişimlere } \\
\text { iliş̧kin Nakit Girişi }\end{array}$ & 0.00 & 0.00 \\
\hline $\begin{array}{l}\text { A7 İşletme Faaliyetleri Varlık ve Yabancı Kaynaklardaki Değişimlere } \\
\text { iliş̧in Nakit Çıkışı (-) }\end{array}$ & 0.00 & 0.00 \\
\hline A8 Dönem Karı Yükümlülüğu Nakit Çıııı̧ı (-) & 0.00 & 0.00 \\
\hline İşletme Faaliyetlerinden sağlanan/kullanılan net nakit akışı & 0.00 & $415,750.00$ \\
\hline B. YATIRIM FAALIYETLERINE ILIŞKIN NAKİT AKIŞLARI & & \\
\hline B1 Yatırım Faaliyetleri Nakit Girişi & 0.00 & 0.00 \\
\hline B2 Yatırım Faaliyetkeri Nakit Çıkışı (-) & 0.00 & 0.00 \\
\hline Yatırım Faaliyetlerinden Sağlanan/Kullanılan Net Nakit Akışı & 0.00 & 0.00 \\
\hline C. FINANSMAN FAALIYETLERINE ILIŞKINN NAKİT AKIŞLARI & & \\
\hline C1 Finansman Faaliyetleri Nakit Girişi & 0.00 & 0.00 \\
\hline C2 Finansman Faaliyetleri Nakit Çıkışı (-) & 0.00 & 0.00 \\
\hline $\begin{array}{l}\text { Finansman Faaliyetlerinden Sağlanan/Kullanılan Net Nakit } \\
\text { Artış/Azalış }\end{array}$ & 0.00 & $-415,750.00$ \\
\hline $\begin{array}{l}\text { Yabancı Para Çevirim Farklarının Etkisinden Once Nakit ve Nakit } \\
\text { Benzerlerindeki Net Artış (Azalış) }(A+B+C)\end{array}$ & 0.00 & $415,750.00$ \\
\hline D1 Kur Farklarınin Olumlu Etkileri & 0.00 & 0.00 \\
\hline Kur Fark1 Etkileri & 0.00 & 0.00 \\
\hline $\begin{array}{l}\text { E. NAKIT VE NAKIT BENZERLERINDE MEYDANA GELEN } \\
\text { NET ARTIS }(+) \text { AZALIŞ (-) }\end{array}$ & 0.00 & 0.00 \\
\hline F. DÖNEMBAŞI NAKİT VE NAKİT BENZERLERİ MEVCUDU & 0.00 & 0.00 \\
\hline G. DÖNEM SONU NAKİT VE NAKİT BENZERLERI MEVCUDU & 0.00 & 0.00 \\
\hline
\end{tabular}




\subsubsection{TDHP Diğer Alacaklar hesap grubunun Finansal Durum Tablosu(Vergi Etkisi Öncesi) (MOMTOS, 2017)}

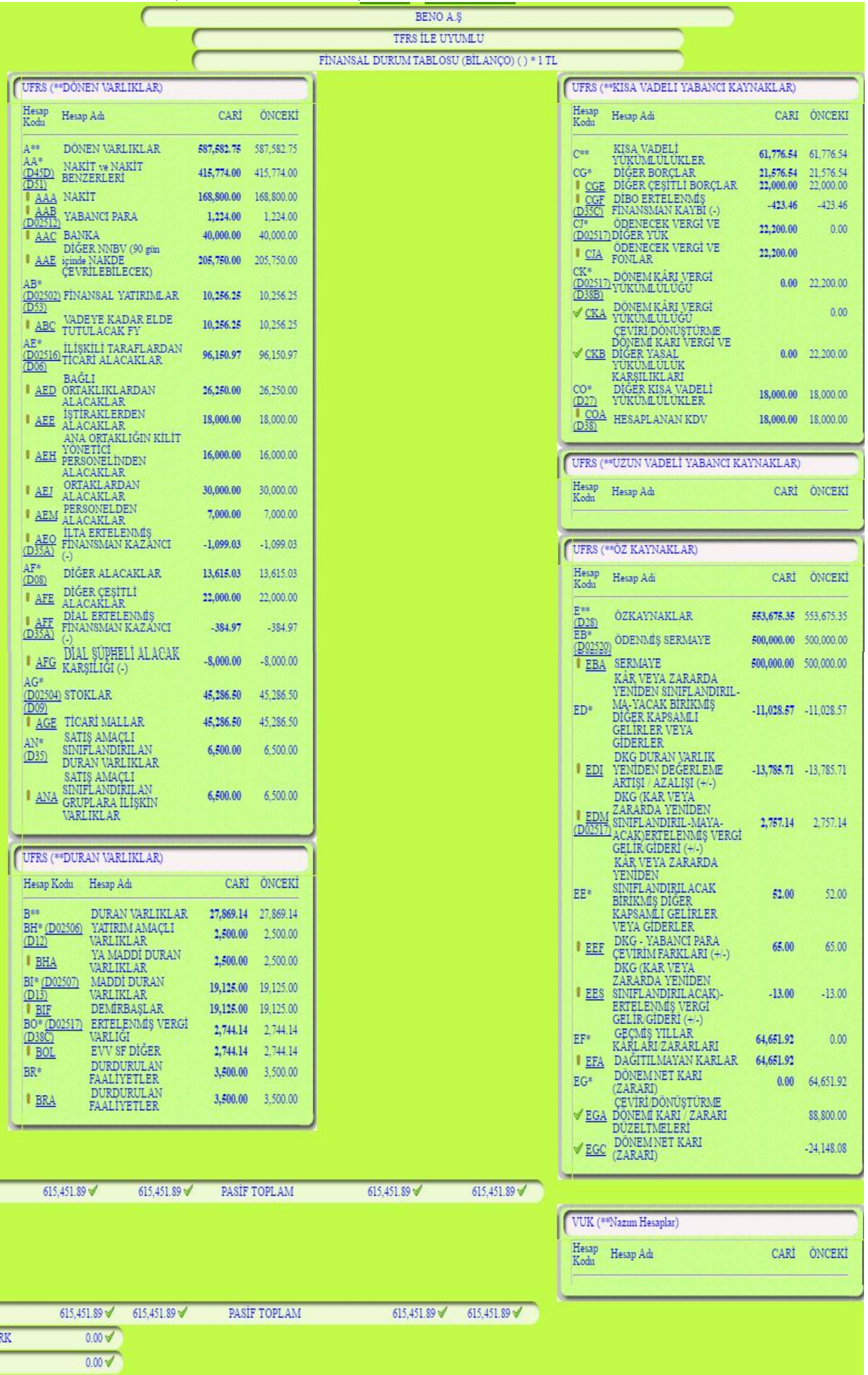

\begin{tabular}{|c|c|c|c|c|c|}
\hline AKTIF TOPLAM & $615,451.89 \mathrm{~d}$ & $615,451.89 \mathrm{~d}$ & PASIF TOPLAM & $615,451.89 \mathrm{~d}$ & $615,451.89 \mathrm{~d}$ \\
\hline ONCEKI TOPLAM FARK & 0.000 & & & & \\
\hline CARI TOPLAM FARR & 0.007 & & & & \\
\hline
\end{tabular}

$\checkmark$ BENO A.Ş. Özkaynaklar Değişim Tablosunun Bakiyeler (Dönem Sonu) bölümündeki Geçmiş Yıllar Kar/Zararlar: 64,651.92 TL, Finansal Durum 
Tablosunun (Bilanço) Özkaynaklar bölümü EG* Dönem Net Karı (Zararı) hesabında gösterilmiştir.

$\checkmark$ BENO A.Ş. Özkaynaklar Değişim Tablosunun Bakiyeler (Dönem Sonu) bölümündeki Özkaynaklar: 553,675.35 TL, Finansal Durum Tablosunun (Bilanço) Özkaynaklar bölümü E** Özkaynaklar hesabında gösterilmiştir.

$\checkmark$ BENO A.Ş. Finansal Durum Tablosunun (Bilanço): 615,451.89 TL olarak AktifPasif denkliği sağlanmıştır.

2.6. TDHP Diğer Alacaklar hesap grubunun ve ilişkili hesapların TFRS'lerin ilk kez uygulandığı 01 Ocak 20XX tarihli Açılış Finansal Tablolarına aktarılmış hali (Vergi Etkisi Sonrası)

TDHP Diğer Alacaklar hesap grubunun ve ilişkili hesapların TFRS'lerin ilk kez uygulandığı 01 Ocak 20XX tarihli Açılış Finansal Tablolarına aktarılmış Finansal Sonuç Tablolarının Vergi Etkisi Sonrası hali Vergi Etkisi Öncesi hali ile aynıdır.

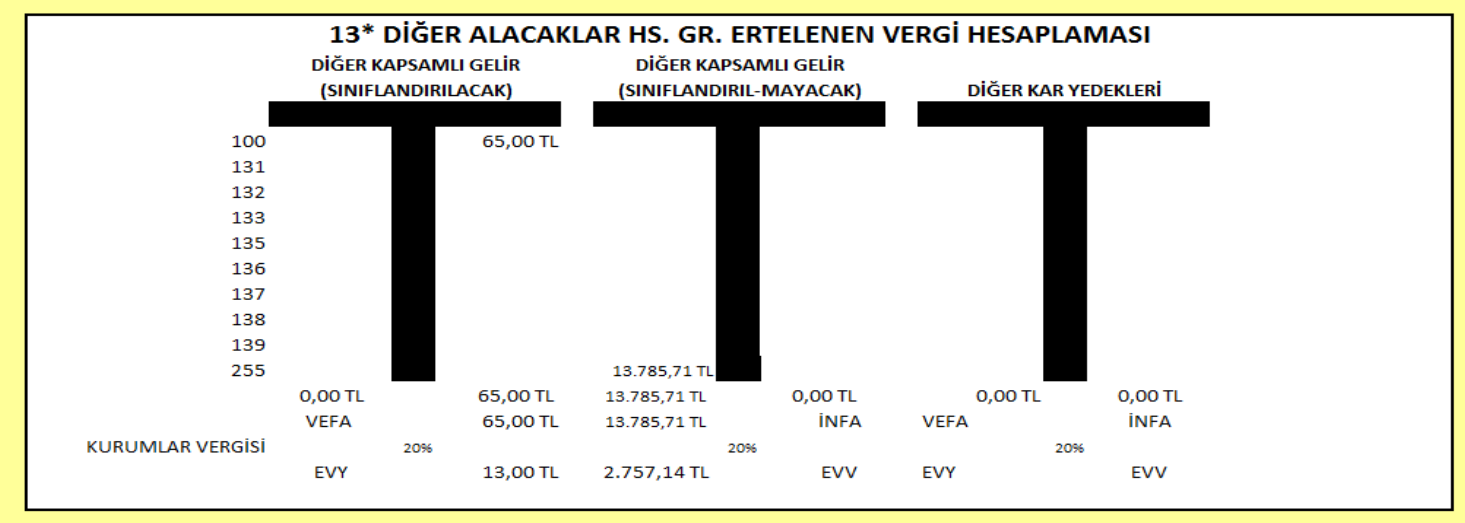

2.6.1. TDHP Diğer Alacaklar hesap grubunun Vergi Etkisi Tablosu (MOMTOS, 2017)

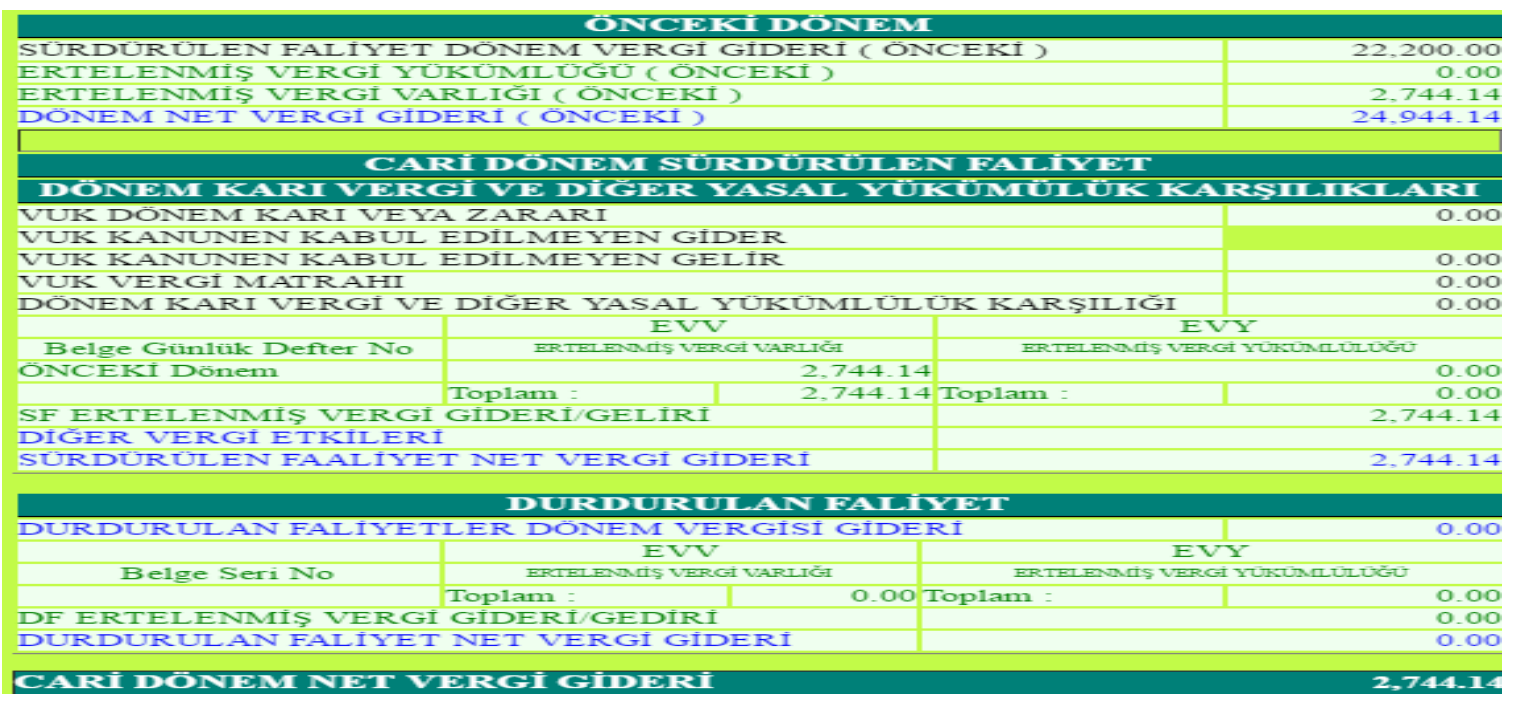

\section{SONUÇ VE ÖNERILLER}

TDHP 13* Diğer Alacaklar hesap grubu için oluşturulan senaryo verilerini www.mumeyek.org adresinde bulunan MOMTOS -DR yazılımında çevirme işlemi 
sonucunda TFRS 'ye göre Finansal Durum Tablosu, Nakit Akış Tablosu, Özkaynaklar Değişim Tablosu, Kar veya Zarar ve Diğer Kapsamlı Gelir Tabloları gibi anlamlı ve tutarlı finansal raporlar elde edilmiştir. Elde edilen bu tablolar neticesinde, işletme dışı bilgi kullanıcılarına ilgili, ihtiyaca uygun, güvenilir, karşılaştırılabilir, doğrulanabilir, anlaşılabilir ve daha kapsamlı faydalı finansal bilgileri sunmuştur.

Şeffaflığın her geçen gün arttığı günümüzde ve özellikle ülkemizdeki işletmelerin küresel piyasada rekabet gücünü arttırma konusunda daha fazla kaynak sağlanması, iç ve dış piyasada uzun vadeli ve düşük faiz oranlı kredi kullanılması, işletme yönetiminin sorumluluklarına ilişkin açık ve net bilgi alınması, net nakit akış girişlerini etkin değerlendirilmesi, çalışanların ücret ve diğer menfaatlerinin adaletli şekilde sağlanması gibi konularda faydalı finansal bilgiler ulusal gelir ve gelecek için büyük önem arz etmektedir. Bu kapsamda yeni Türk Ticaret Kanunu çerçevesinde değerlendirilen işletmeler finansal raporlarını TFRS 'ye göre oluşturarak gerçeğe uygun bir şekilde zamanında sunulması işletme dışı bilgi kullanıcıları için daha faydalı olabileceği düşünülmektedir.

\section{KAYNAKÇA}

Erdoğan, M. (2013). TFRS Model Hesap Planı. İstanbul: MUMEYEK Vakfı Yayını.

Erdoğan, M. (2012). VUK'ndan TFRS'na Geçiş Rehberi, TFRS Model Hesap Planl. İstanbul: MUMEYEK Vakfı Yayını, No:01, ISBN:987-605-61870-1-8.

MOMTOS (2017). Mumeyek Online Mali Tablo Oluşturma Sistemi Web sitesi: https://www.mumeyek.org adresinden alınmıştır.

Resmi Gazete (1992, Aralık 26). Muhasebe Sistemi Uygulama Genel Tebliği (Stra No:1), Resmi Gazete, Sayı:21447, 26 Aralık 1992, ss.44,58.

Resmi Gazete (2011) Finansal Raporlamaya Ilişkin Kavramsal Çerçeve Tebliği, Resmi Gazete, Say1:27828, 27 Ocak 2011.

TFRS1 (2017). Şubat 8, 2017 tarihinde Kamu Gözetimi Muhasebe ve Denetimi Standartları Kurumu Web Sitesi: http://kgk.gov.tr/Portalv2Uploads/files/DynamicContentFiles/T\%C3\%BCrkiye\%20Muh asebe\%20Standartlar\%C4\%B1/TMSTFRS2016Seti/TFRS_1.pdf adresinden alınd, Türkiye Finansal Raporlama Standartlarının İlk Uygulaması (TFRS 1)

TMS24 (2017). Şubat 8, 2017 tarihinde Kamu Gözetimi Muhasebe ve Denetimi Standartları Kurumu Web Sitesi: http://kgk.gov.tr/Portalv2Uploads/files/DynamicContentFiles/T\%C3\%BCrkiye\%20Muh asebe\%20Standartlar\%C4\%B1/TMSTFRS2016Seti/TMS24.pdf adresinden alındı, Türkiye Muhasebe Standartları-24, İlişkili Taraf Açıklamaları

TMS28 (2017). Şubat 8, 2017 tarihinde Kamu Gözetimi Muhasebe ve Denetimi Standartları Kurumu

Web

Sitesi: http://kgk.gov.tr/Portalv2Uploads/files/DynamicContentFiles/T\%C3\%BCrkiye\%20Muh asebe\%20Standartlar\%C4\%B1/TMSTFRS2016Seti/TMS28.pdf adresinden alındı, Türkiye Muhasebe Standartları-28, İştiraklerdeki ve İş Ortaklıklarındaki Yatırımlar. 